\title{
Review
}

\section{SARS-CoV-2/COVID-19 and Advances in Developing Potential Therapeutics and Vaccines to Counter this Emerging Pandemic Virus - A Review}

\author{
Ali A. Rabaan, ${ }^{1}$ Shamsah H. Al-Ahmed, ${ }^{2}$ Ranjit Sah, ${ }^{3}$ Ruchi Tiwari, ${ }^{4}$ Mohd. Iqbal \\ Yatoo, ${ }^{5}$ Shailesh Kumar Patel, ${ }^{6}$ Mamta Pathak, ${ }^{6}$ Yashpal Singh Malik, ${ }^{7}$ Kuldeep \\ Dhama, ${ }^{6 *}$ Karam Pal Singh ${ }^{6}$, D. Katterine Bonilla-Aldana, ${ }^{8,9}$ Shafiul Haque, ${ }^{10}$ Alfonso J. \\ Rodriguez-Morales., ${ }^{9,11 *}$
}

\footnotetext{
${ }^{1}$ Molecular Diagnostic Laboratory, Johns Hopkins Aramco Healthcare, Dhahran, Saudi Arabia.

${ }^{2}$ Specialty Paediatric Medicine, Qatif Central Hospital, Qatif, Saudi Arabia.

${ }^{3}$ Department of Microbiology, Tribhuvan University Teaching Hospital, Institute of Medicine, Kathmandu, Nepal.

${ }^{4}$ Department of Veterinary Microbiology and Immunology, College of Veterinary Sciences, UP Pandit Deen Dayal Upadhayay Pashu Chikitsa Vigyan Vishwavidyalay Evum Go-Anusandhan Sansthan (DUVASU), Mathura 281001, India.

${ }^{5}$ Sher-E-Kashmir University of Agricultural Sciences and Technology of Kashmir, Shalimar, 190025 Srinagar, Jammu and Kashmir, India.

${ }^{6}$ Division of Pathology, ICAR-Indian Veterinary Research Institute, Izatnagar 243 122, Bareilly, Uttar Pradesh, India.

${ }^{7}$ Division of Biological Standardization, ICAR-Indian Veterinary Research Institute, Izatnagar, Bareilly- 243 122, Uttar Pradesh, India.

${ }^{8}$ Semillero de Zoonosis, Grupo de Investigación BIOECOS, Fundación Universitaria Autónoma de las Américas, Sede Pereira, Pereira, Risaralda, Colombia;

${ }^{9}$ Public Health and Infection Research Group, Faculty of Health Sciences, Universidad Tecnologica de Pereira, Pereira, Colombia

${ }^{10}$ Research and Scientific Studies Unit, College of Nursing \& Allied Health Sciences, Jazan University, Jazan, Saudi Arabia

${ }^{11}$ Grupo de Investigacion Biomedicina, Faculty of Medicine, Fundacion Universitaria Autonoma de las Americas, Pereira, Risaralda, Colombia
}

Running Title: COVID-19 Threats, Therapeutics and Vaccines

Corresponding Author(s):

Kuldeep Dhama, PhD (kdhama@rediffmail.com), Division of Pathology, ICAR -Indian Veterinary Research Institute, Izatnagar, Bareilly, India.

Alfonso J Rodriguez-Morales, HonDSc (arodriguezm@utp.edu.co), Public Health and Infection Research Group, Faculty of Health Sciences, Universidad Tecnologica de Pereira, Pereira, Colombia.
Abstract length: 288 words
Figures and tables: 4 (2 figures and 2 tables)
Manuscript length: 12000 words 


\begin{abstract}
A novel coronavirus (SARS-CoV-2), causing an emerging coronavirus disease (COVID-19), first detected in Wuhan City, Hubei Province, China has resulted in an outbreak in China which has taken a catastrophic turn with high toll rates in China and subsequently spreading across the globe. The rapid spread of this virus to more than 175 countries while affecting nearly 500,000 persons and causing more than 22,000 human deaths, it has resulted in a pandemic situation in the world. The SARS-CoV-2 virus belongs to the genus Betacoronavirus, like MERS-CoV and SARS-CoV, all of which originated in bats. It is highly contagious, causing symptoms like fever, dyspnea, asthenia and pneumonia, thrombocytopenia and the severely infected patients succumb to the disease. Coronaviruses (CoVs) among all known RNA viruses have the largest genomes ranging from 26 to $32 \mathrm{~kb}$ in length. Extensive research has been conducted to understand the molecular basis of the SARS-CoV-2 infection and evolution, develop effective therapeutics, antiviral drugs and vaccines, and to design rapid and confirmatory viral diagnostics as well as adopt appropriate prevention and control strategies. Till date, no clinically proclaimed, proven therapeutic antibodies or specific drugs and therapeutics, and vaccines have turned up. Several molecular diagnostic tests such as Real Time-PCR, isothermal loop-mediated amplification of coronavirus (i-LACO), full genome analysis by next-generation sequencing (NGS), multiplex nucleic acid amplification, and microarray-based assays are in use currently for the laboratory confirmation of this $\mathrm{CoV}$ infection. In this review article, we describe the basic molecular organization and phylogenetic analysis of the coronaviruses, including the SARS-CoV-2, and recent advances in diagnosis and vaccine development in brief and focusing mainly on developing potential therapeutic options that can be explored to manage this pandemic virus infection, which would help in valid countering of COVID-19.
\end{abstract}

Keywords: SARS-CoV-2, COVID-19, immunotherapeutics, therapeutics, vaccines

\title{
1. Introduction
}

Since December 2019, a pneumonia-like Coronavirus emerged in Wuhan, China. Within a few weeks, a novel coronavirus was given a nomenclature as 2019 novel coronavirus (2019$\mathrm{nCoV}$ ) by the World Health Organization (WHO) (https://www.who.int/emergencies/diseases/novel-coronavirus-2019) and severe acute respiratory syndrome coronavirus-2 (SARS-CoV-2) by International Committee on Taxonomy of Viruses (ICTV) (Gorbalenya et al., 2020), causing the disease termed as an emerging coronavirus disease (COVID-19). Since then, this virus has spread to every populous continent and infected thousands around the world - through the vast majority of confirmed cases, and fatalities fall within China and spreading to Italy, Iran, South Korea, France, Spain, USA, Japan, Spain, and many others. COVID-19 has now spread to 175 countries with nearly 500,000 confirmed cases and 22,000 human deaths, and most recently (on $11^{\text {th }}$ March 2020) WHO proposed it as a pandemic situation worldwide (WHO, 2020a; Yang et al., 2020a). Unlike other coronavirus epidemics like SARS and MERS, the transmission rate of COVID-19 is much higher with spreading of the virus infection to an average of two to three individuals from every infected individual (Gates et al., 2020). 
Travellers have been mainly implicated in giving wings to SARS-CoV-2 for its worldwide spread (Rodriguez-Morales et al., 2020a; Wilson and Chen, 2020). The new strain of the virus that originated in Wuhan, Hubei province of China is spreading rapidly and crossing borders. Most of the affected patients in China worked at or lived in Huanan seafood wholesale market, where live animals like snakes, bats, birds, marmots, and other wildlife farm animals were sold (Ji et al., 2020). Wuhan is now considered a hotspot for emerging infectious disease. The virus did not match with the existing known viruses. Several cases of pneumonia were reported from 31 ${ }^{\text {st }}$ December 2019 with unknown aetiology in Wuhan, China (Chen et al., 2020a). The SARS-CoV-2 virus belongs to the family of viruses that include the common cold, and viruses of SARS and MERS (Vijayanand et al., 2004; Ramadan and Shaib, 2019; Peeri et al., 20202. It affects humans leading to respiratory infection and animals including cattle, camels, swine, cats, horses, rabbits, birds, bats, dogs, ferrets, rodents, snake, mink, and causes multiple system infection (Dhama et al., 2020a). Infected patients develop a high fever, dyspnea, pneumonia, chest pain, dry cough, myalgia and diarrhoea as clinical signs of the disease (Bassetti et al., 2020; Huang et al., 2020).

Structures of many individual proteins of SARS, MERS, and related coronaviruses, as well as their biological interactions with other viral and host proteins, have been explored along with the experimental testing of anti-viral properties of small compounds (Gui et al., 2017; Jia et al., 2019; Galasiti Kankanamalage et al., 2018). Till date, there are still not proclaimed clinically proven therapeutic antibodies, drugs and vaccines specific for coronaviruses, which makes it tougher to tackle SARS-CoV-2 caused diseases. This article, in brief, describes the molecular organization and phylogenetic analysis of the coronaviruses including the SARSCoV-2 highlights a few advances in diagnosis and vaccine development and emphasizes in details on the different potential therapeutic options that could be pursued for therapy despite limited knowledge of the biology of SARS-CoV-2 such as neutralizing antibodies, oligonucleotides, passive antibody transfer and drug repurposing, anti-viral proteases, blocking Coronavirus receptors like an angiotensin-converting enzyme (ACE2), combination therapy, which can bring a revolutionary change to curb the SARS-CoV-2 / COVID-19 in the coming future.

\section{Coronaviruses}

Coronaviruses, members of the family Coronaviridae are enveloped, positive-stranded RNA viruses which appear to demonstrate spikes of glycoproteins protruding from their viral envelopes, thus exhibit a corona or halo-like appearance (Masters and Perlman, 2013; Cui et al., 2019). Earlier coronaviruses were found to be the causative agents for a broad spectrum of respiratory and gastrointestinal diseases in both wild and domestic animals, including birds, pigs, rodents, among others (Dhama et al., 2014, 2020a). Previous studies have found that six strains of CoVs are capable of infecting human, among which four strains circulate yearly to cause the common cold, and other two strains which are the source for severe acute respiratory syndrome (SARS) and the Middle East respiratory syndrome (MERS-CoV), respectively (Perlman and Netland, 2009; Dhama et al., 2014, 2020a; Cui et al., 2019; Ramadan and Shaib, 2019; Liu et al., 2020a). 
Coronaviruses, among all known RNA viruses, have the largest genomes ranging from 26 to $32 \mathrm{~kb}$ in length (Regenmortel et al., 2000; Schoeman and Fielding, 2019). In addition to encoding structural proteins, a significant chunk of the coronavirus genome is transcribed and translated into a polypeptide, which encodes proteins essential for viral replication and gene expression (Lai and Holmes, 2001). The 306 aa long main protease (Mpro), which is a highly conserved sequence, is a crucial enzyme for coronavirus replication (Lai and Holmes, 2001). Mpro has been utilized for developing anti-coronaviral drugs (Xue et al., 2008; Anand et al., 2003). Nevertheless, in the past two decades, a massive amount of research has been done to understand the replication, molecular basis of the coronavirus infection and evolution, develop effective therapy in forms of both vaccines and antiviral drugs, and propose efficient measures for viral detection and prevention (Perlman and Netland, 2009; Cotten et al., 2013; Li et al., 2016; Walls et al., 2016; Millet and Whittaker, 2018; Song et al., 2018; Chen et al., 2020b; Dhama et al., 2020a).

\section{Taxonomy and Classification}

ORDER: Nidovirales

FAMILY: Coronaviridae

SUB FAMILY: Coronavirinae

GENERA: Betacoronavirus

The coronavirus belongs to the Coronaviridae family, Nidovirales order (Huang., 2020). The International Committee on Taxonomy of Viruses (ICTV) had broadly divided Coronaviruses into four genera: Alphacoronavirus, Betacoronavirus, Gammacoronavirus, and Deltacoronavirus (van Boheemen et al., 2012). There have been outbreaks of human coronavirus (HCoVs) in the past: $\mathrm{HCoV}-229 \mathrm{E}$ and $\mathrm{HCoV}-\mathrm{OC} 43$ outbreak in the late sixties, HCoV-NL63 in 2004, and HCoV-HUK1 in 2005. There are another two types of betacoronaviruses (zoonotic pathogens) that resulted in outbreaks in the past: SARS-CoV outbreak in Guangdong, southern China in November 2002 infected 8422 patients across the world over 29 countries (Chen et al., 2020b, Lu et al., 2020a) and MERS-CoV outbreak in Saudi Arabia in 2012 infected 2,260 cases that resulted in 803 deaths over 27 countries (Geller et al., 2012; Ramadan and Shaib, 2019). Apart from that, another coronavirus emerged in 2017, known as the swine acute diarrhoea syndrome (SADS) coronavirus (Markotter et al., 2019). Table 1 describes the broad classification of the coronavirus.

\section{Phylogenetic analysis and Genomic organization}

Recent phylogenetic analysis has revealed that the new virus spreading in China is a version of SARS-CoV. There are two significant similarities between SARS-CoV-2 (nCoV-2019) and SARS-CoV: they share nearly $80 \%$ of their genetic codes, and both are originated in bats (Malik et al., 2020; Zhu et al. 2020). The first study to analyze the viral genome analysis was conducted in the Wuhan Institute of Virology. Samples from seven patients initially reported cases of severe pneumonia were used for the analysis. It was found that the new virus genetic sequences were $79.5 \%$ similar to SARS-CoV (https://www.businessinsider.in/science). 
The genome of CoVs consists, a single-stranded, positive-sense RNA of around $29.8 \mathrm{~kb}$ nucleotides in length with a 5'-cap structure and 3'-polyA tail. The polyprotein 1a/1ab (ppla/pplab) is directly translated using genomic RNA as a template, which encodes nonstructural proteins (nsps) and forms the replication-transcription complex (RTC). Also, a nested set of subgenomic RNAs (sgRNAs) are produced by replication-transcription complex in a discontinuous manner of transcription. It has common 5'-leader sequences and 3'terminal sequences. Transcription termination and acquisition of leader RNA happens at transcription regulatory sequences, which are located between open reading frames (ORFs). These sgRNAs (minus-strand) acts as the templates for the synthesis of subgenomic mRNAs (Perlman and Netland, 2009; Chen et al., 2020b; Dhama et al., 2020a)

A typical CoV's genome and subgenome contain at least six ORFs. The first ORF (ORF1a/b), contains two-third of the whole length genome and encodes 16 nsps (nsp1-16). A-1 frameshift between ORF1b and ORF1a, leads to the synthesis of two polypeptides: pp1ab and ppla. These are processed by chymotrypsin-like protease or two papain-like protease or main protease and one into $16 \mathrm{nsps}$. Rests of the ORFs of the genome encode four major structural proteins: membrane $(\mathrm{M})$, spike $(\mathrm{S})$, nucleocapsid $(\mathrm{N})$ and envelope $(\mathrm{E})$ proteins. Other than these proteins, different CoVs encode specific accessory proteins and structural proteins, such as 3a/b protein, HE protein and 4a/b protein (Perlman and Netland, 2009; Chen et al., 2020b; Dhama et al., 2020a).

The genomic sequence alignment among different CoVs shows 58\% identity on the nonstructural protein-coding region, $43 \%$ identity on the structural protein-coding region, with $54 \%$ at the whole genome level which suggests the non-structural proteins are more conserved when compared to the structural proteins and structural proteins are more diverse when in need of adaptation for new hosts. However, the $\mathrm{CoV}$ genome is extensive, with $\sim 30 \mathrm{~kb}$ in length and is considered as the largest known RNA viruses. Such a large genome of CoVs is maintained by the unique features of the CoV RTC, which encodes for many RNA processing enzymes. The 3'-5' exoribonuclease is one such kind of RNA processing enzyme and is unique in CoVs among different RNA viruses, also believed for providing a proofreading function to the RTC. Sequence analysis depicts that the SARS-CoV-2 has a typical genome structure same as of $\mathrm{CoV}$ and mainly belongs to the Betacoronaviruses cluster, which includes Bat-SL ZXC21, Bat-SARS-like (SL)-ZC45, SARS-CoV, and MERSCoV (Chen et al., 2020b; Dhama et al., 2020a). The glycoprotein spike surface plays an essential role in receptor binding and determines host tropism (Zhu et al., 2018). These proteins of SARS-CoV and MERS-CoV bind via different receptor-binding domains (RBDs) to various host receptors. SARS-CoV utilizes angiotensin-converting enzyme 2 (ACE2) as the primary receptor and MERS-CoV utilizes dipeptidyl peptidase 4 (DPP4, also known as CD26) as the primary receptor. Initial analysis depicted that SARS-CoV-2 has a quite close phylogenetic association with SARS-like bat coronaviruses. (Malik et al., 2020; Zhou et al., 2020)

Comparison of genomes of SARS-CoV-2, SARS-CoV and MERS-CoV strains suggested that they are almost identical and possess only five nucleotide differences in the genome. The 
SARS-CoV-2 genome annotation shows that they possess 14 ORFs encoding for 27 different proteins. The orf1a and orf1ab genes of the genome, respectively encode the pp1a and pp1ab proteins. They together possess $15 \mathrm{nsps}$, from nsp 1 to nsp10 and nsp12 to nsp16. The genome also contains eight accessory proteins and four structural proteins ( $\mathrm{S}, \mathrm{E}, \mathrm{M}$, and N). The SARS-CoV-2 is quite similar to that of SARS-CoV, at the amino acid level. Also, there are some differences. For example, the $8 \mathrm{~b}$ protein is 84 amino acids in SARS-CoV, whereas in 2019-nCoV, 8b protein has 121 amino acids; the 8a protein is present in SARS-CoV but absent in SARS-CoV-2 (Chen et al., 2020b; Dhama et al., 2020b)

An observation of the amino acid substitutions in different proteins occurs among them, and this sheds light into how SARS-CoV-2 differs from SARS-CoVs structurally and functionally. In total, 380 amino acid substitutions were there between the SARS-CoV-2 amino acid sequences and the SARS and SARS-like viruses. However, no amino acid substitutions were found in nonstructural protein 7 (nsp7), envelope, nsp13, matrix, or accessory proteins 8b and p6. Nevertheless, due to minimal knowledge about this novel virus, it is quite hard to give reasonable explanations for the amino acid substitutions between the SARS-CoV-2 and SARS or SARS-like CoVs and also whether these differences could affect the host transmission property of the SARS-CoV-2 when compared to SARS-CoV needs future investigation (Wu et al., 2020a).

SARS-CoV-2 became the seventh member of the human coronaviruses (HCoVs) identified as HCoV-229E, HCoV-OC43, HCoV-NL63, HCoV-HKU1, SARS-CoV (which causes severe acute respiratory syndrome), MERS-CoV (Middle East respiratory syndrome), and now SARS-CoV-2 (Rhode, 2020).

\section{The emergence of Coronaviruses (SARS-CoV, MERS CoV and SARS-CoV-2)}

The Coronaviruses were known to cause only mild respiratory disease in humans; with severe infections in the immunocompromised cases and young kids mainly acting as an asymptomatic carrier as disease symptoms are not much prominent in young ones (Shen et al., 2020). Coronaviruses have the highest known frequency of recombination of any positivestrand RNA virus (Rohde, 2020). Earlier reports suggested the emergence of SARS-CoV by recombination between bat SARS related coronaviruses (SARSr-CoVs) followed by mutations in civets before its spillover. Similarly, the MERS-CoV also circulated and attained mutations for around 30 years in camels before the MERS pandemic happened (Muller et al., 2014; Cui et al., 2019), suggesting the adaptation of the viruses to the environment and different host before their spillover to humans (Ellwanger and Chies, 2018). Coronaviruses also have an essential replication process, which involves a 2-step replication mechanism. Many RNA virus genomes contain a single open reading frame (ORF), but coronaviruses can contain up to 10 separate ORFs except for SARS-CoV-2, which has single intact ORF (Rohde, 2020). That can lead to the emergence of $\mathrm{CoV}$ at times.

\subsection{SARS-CoV}

SARS-CoV emerged first in the Guangdong Province of China; and spread internationally to 37 different countries. Noteworthy outbreak sites included China, Hong Kong, Taiwan, 
Singapore, and Vietnam. However, outside the Southeast Asia area, Canada was also significantly affected. WHO reported 8,437 SARS cases and 813 deaths between the period of November 2002 to July 2003. Transmission is presumed to be from Chinese horseshoe bats harbouring SARS-like viruses directly to humans or via intermediate hosts, i.e. palm civets or raccoon dogs in the live-animal markets of China. The employment of control measures inclusive of quarantine and air travel blockade, ultimately resulted in the disappearance of SARS-CoV in 2003, with no human infections reported ever since (Vijayanand et al., 2004; WHO, 2020b)

\subsection{MERS-CoV}

MERS-CoV was first identified in the Kingdom of Saudi Arabia in 2012. Cases have been geographically restricted to the Arabian Peninsula. However, a smaller number of cases were also found in Europe, i.e. in people who had travelled to the Arabian Peninsula or had been in contact with people who had. Individual cases and small clusters continue to be reported in that region. MERS-CoV is thought to be transmitted from camels to humans, with the possibility that at some point bats infected camels. MERS-CoV is thought to have emerged from bats or other small animals, and have infected humans via dromedary camels acting as intermediate hosts (Ramadan and Shaib, 2019; WHO, 2020c).

\subsection{SARS-CoV-2}

A novel (new) coronavirus (SARS-CoV-2) that was first detected in Wuhan City, Hubei Province, China is posing a significant threat now by creating a pandemic situation of the COVID-19 (WHO, 2020d; Yang et al., 2020a). The first case was detected in December 2019, and presently nearly 500,000 confirmed cases detected (WHO, 2020a). The disease terrorized over 175 countries/territories/areas with 22,000 deaths which is probably not the last figure to be known (WHO, 2020a). In early March 2020, the pandemic started to subside in China (Flahault, 2020) but started to haunt Europe and the United States. In this context, other than China, the major blow was felt by Italy, Spain, Iran and France with 7500, 3,650, and 2077 deaths, respectively but the pain of countries like France (1,330 deaths), USA (944 deaths), UK (465 deaths), Republic of South Korea (126 deaths), Netherlands (356 deaths) and Germany (206 deaths) could not be overlooked.

However, only a few countries are left beyond the reach of this unfortunate pandemic, but their possibility of remaining untouched by this pathetic virus is meagre because within a short period the virus emerged in many new countries including India where two individual recently got victimized. Now the number of new confirmed cases and deaths are shooting day by day with no hope of sudden halt leaving the global population in a stage of physiological, psychological, and socioeconomic stress. In a study, the psychological stress of general public along with nurses involved in the treatment of COVID-19 patients was evaluated based on vicarious traumatization scores and revealed that the scores were found significantly higher for the general public than nurses (Li et al., 2020a).

The origin of SARS-CoV-2 was postulated to be from bats, considering them the natural reservoirs of the virus (Chan et al., 2020a). The search of probable intermediate hosts is going 
on keeping the main focus on animal species available for sale in Huanan seafood market. Recently, a study suggested the pangolins to serve as a natural reservoir host of SARS-CoV2-like coronaviruses (Pangolin-CoV) based on 91.02\% sequence similarities at the wholegenome level between pangolin-CoV and SARS-CoV-2. Additionally, the S1 protein of pangolin coronavirus was reported to be more closer to SARS-CoV-2 than bat coronavirus (RaTG13) (Zhang et al., 2020a). Initially, the disease was thought to be spreading via seafood consumption, but later contact transmission of SARS-CoV-2 among humans was confirmed. In nearby places like clinics and hospitals, $\mathrm{CoV}$ can be transmitted through the air if people remain there for a long duration of time, suggesting the risk of aerosol transmission (Cascella et al., 2020).

The emergence of SARS-CoV in 2002 established CoVs as capable of causing severe disease in humans. This ability was once again demonstrated by the emergence of a second severe $\mathrm{CoV}$ a decade later; the MERS-CoV in 2012. The MERS-CoV and SARS-CoV emergence are believed to be the result of spill-over of bat-adapted CoVs into an intermediate host. They are transmitted from person to person through respiratory droplets and close contact (https://www.cdc.gov/coronavirus/types.html). The virus is believed to be transmitted to patients living in or working at areas in proximity to wholesale seafood markets and places where live animals like snakes, bats, birds, marmots, and other wild or farm animals were sold (Ji et al., 2020). Rarely animal coronaviruses infect humans severely except for SARSCoV, MERS-CoV and now SARS-CoV-2. Seldom coronaviruses cause lower respiratory infection or pneumonia but SARS-CoV-2 causes. Coronaviruses have seasonal pattern usually affecting in winter, however, can infect out of season also (Rohde, 2020).

\section{COVID-19 Clinical Pathology}

The coronavirus claimed its first life on January $10^{\text {th }}, 2019$, and since then the death toll has climbed at an alarming and accelerating rate. The virus seems lethal, causing severe acute respiratory symptoms, including fever, dyspnea, asthenia and pneumonia, thrombocytopenia, and increased C-reactive protein and lactate dehydrogenase levels among people in Wuhan, China (Zhu et al., 2020; Lu et al., 2020b). As per reports, mild COVID-19 cases revealed higher levels of pro-inflammatory cytokines and chemokines like IFN- $\alpha$, IL-1 $\beta$, MCP-1 and IP-10 whereas individuals with severe COVID-19 had upregulation of IP-10, IL-8, IL-10, TNF- $\alpha$, G-CSF, MCP-1 and MIP-1A (Huang et al., 2020; Qin et al., 2020) resulting into cytokine storm syndrome followed by severe pulmonary damage and death due to respiratory failure. Additionally, all the blood cells except neutrophils were reported to be decreased with fall in lymphocytes subsets like T cells, B cells and NK cells in severe COVID-19 cases (Qin et al., 2020). Chest radiographs show invasive lesions in both lungs with flaws of a variable degree in the lungs. Additionally, bilateral multilobular subsegmental consolidation, groundglass opacity with many mottling was also reported in the COVID-19 patients (Bassetti et al., 2020; Huang et al., 2020). Recently, myalgia and fatigue are found associated with rhabdomyolysis in a COVID-19 patient in Wuhan, China suggesting the need of rapid clinical diagnosis followed by favourable hydration treatment to reduce the risk of severe outcomes as a result of rhabdomyolysis (Jin and Tong, 2020). 
Additionally, COVID-19 patients may also manifest neurological signs such as headache, nausea and sometimes vomiting, but even dysgeusia and anosmia. Moreover, SARS-CoV infection has been reported in nervous tissue of experimental animals and patients with heavy involvement of brainstem. In this context, acute respiratory failure in COVID-19 patients suggests the probable invasion of the brain by SARS-CoV-2 (Li et al., 2020b). Recently, a study supported the neurotropic potential of the SARS-CoV-2 virus as $36.4 \%$ of involved COVID-19 patients manifested neurological signs (Mao et al., 2020). Those who developed severe pneumonia, pulmonary oedema, hypoxemic respiratory failure, gastrointestinal infection, multiple system failure or Acute Respiratory Distress Syndrome (ARDS) succumb to the disease. The threat is still looming high on the event of this deadly virus created a pandemic situation (Gralinski and Menachery, 2020; Greenland et al., 2020; Guo et al., 2020; WHO, 2020a; Yang et al., 2020a).

\section{COVID-19 Diagnostics}

Several molecular diagnostics tests such as Real Time-PCR for genes encoding the internal RNA-dependent RNA polymerase and Spike's receptor binding domain, full genome analysis by next-generation sequencing (NGS), isothermal loop-mediated amplification of coronavirus (i-LACO), multiplex nucleic acid amplification, and microarray-based assays are in use currently for the laboratory confirmation of coronavirus infection (Chan et al., 2020b; Yu et al., 2020a; Zhang et al., 2020b). Diagnostic tests for SARS-CoV-2/ COVID-19 cases include viral genome sequencing, RT-PCR, real-time RT-PCR (rRT-qPCR), POCT/bedside testing, reverse transcriptional loop-mediated isothermal amplification (RT-LAMP), serological assays (enzyme-linked immunoassay, ELISA), computed tomography technique (CT) imaging, X-Ray (Corman et al. 2012; Dhama et al. 2020a; Huang et al. 2020; Xu et al. 2020; Zhang et al. 2020b; Yu et al. 2020a). A reverse real-time PCR assay (rRT-PCR) is required for useful and timely screening of COVID-19 patients, which can be carried out in clinical samples like fibre bronchoscope brush biopsies, bronchoalveolar lavage, nasal swabs, pharyngeal swabs, sputum, blood and faeces (Wang et al., 2020a). An interactive web-based dashboard for monitoring COVID-19 in real-time mode has also been reported (Dong et al. 2020). A fluorescence-based quantitative PCR assay based on SARS-CoV-2 N and ORF1ab regions has been developed (Wang et al. 2020b). Moreover, testing for COVID-19 requires travelling to a clinical setting that could lead to increased risk of disease transmission hence a rapid, cheap, user-friendly and sensitive diagnostic tool must be developed for use by ordinary people in their homes (Yang et al., 2020b). In this context, a potential RNA-based POCT diagnostic device which combines a LAMP assay technology and a paper-based POCT was described as a home-based highly accessible and sensitive COVID-19 diagnostic tool with the additional advantage of smartphone integration enabling the individuals to record and share the results with healthcare workers and subsequent clinical care (Yang et al., 2020b).

\section{COVID-19 immunotherapeutics and therapeutics}

SARS-CoV-2 is now growing as a potential emerging pandemic (WHO, 2020a; Yang et al., 2020a). The lessons learned from earlier SARS-CoV-2 and MERS-CoV threats, recent and past epidemics and pandemics situations of Ebola, Zika, Nipah, swine flu, avian/bird flu led 
to make tremendous advances in science and research for developing suitable vaccines and therapeutics/drugs, which along with the current research advances on COVID-19 are warranted to be explored optimally (Dhama et al. 2012, 2013, 2018a, 2018b, 2020b; Munjal et al. 2017; Singh et al. 2017, 2018, 2019; Di Pierro et al. 2020; DST and Health Commission China 2020; Li et al. 2020c; Peeri et al., 2020). The novel coronavirus is spreading rapidly from human to human with a wide range of clinical symptoms like fever, cough, myalgia and fatigue with pneumonia (Zhu et al., 2020, Chan et al., 2020b; Huang et al., 2020). To overcome the symptoms of novel coronavirus pneumonia, as per the severity of patient, sedatives, analgesics, oxygen therapy, and ventilator facility should be provided (Qiu et al., 2020).

Due to the alarming situation in the city of Wuhan and other cities of China, these cities have been shut down to limit the spread of the virus. The current situation resembles the situation that happened with SARS in the 2002-2003 outbreak and the Ebola outbreak in 2014-2015 (Singh et al., 2017). During this outbreak, special quarantine rules and protocol were set up to limit and identify the patient's contact risk. There were no unique antiviral treatments available for SARS and Ebola at the time of outbreaks as situations were beyond control similar to SARS-CoV-2 outbreak. As the structure of the virus is known, so to prevent the virus entry and replication within the body of the host, various inhibitors producing hurdles at different steps are explored and tested in cell-based systems (Kilianski and Baker, 2014; Pillaiyar et al., 2020). They involve spike (S) protein inhibitors, S cleavage inhibitors, helicase and protease inhibitors, fusion core blockers, mAbs against host cell receptor, antiviral peptide targeting S2, RBD-ACE2 blockers, antiviral peptides, siRNAs, neutralizing antibodies, convalescent-phase plasma, repurposed drugs, among others (Du et al. 2009; Chan et al., 2015; Zumla et al., 2016; Dhama et al., 2020b; Lu, 2020). During the current outbreak and pandemic situation, patients require immediate treatment. The below sections will emphasize on different potential treatment options that could be pursued for therapy despite limited knowledge of the biology of SARS-CoV-2.

\subsection{Developing Neutralizing antibodies}

In general, the replication of coronavirus starts with the entry of S protein, which binds to the surface of the cells. This $\mathrm{S}$ protein fuses with the cell membrane and helps the syncytial formation and delivering of viral nucleocapsids into the cell for further replication (Tortorici et al., 2019). As per reports, neutralizing antibodies against receptor-binding domain (RBD) of S protein of SARS-CoV (Traggiai et al., 2004) and MERS-CoV (Corti et al., 2015; Chen et al., 2017; Wang et al., 2018) successfully neutralized those infections. In this context, neutralizing antibodies may prove highly useful in treating the COVID-19 as long as the SARS-CoV-2 shares the sequences in the RBD with SARS-CoV and MERS-COV (Yu et al., 2020b).

S protein was targeted for developing a neutralizing antibody therapy to combat the novel coronavirus disease (Casadevall et al.,2015). Methods such as phage or yeast display libraries which express antibody fragments could be used efficiently to identify the candidate neutralizing antibody. Traditional methods of screening such as mice or rabbits for 
neutralizing antibodies would be too late during outbreaks. The only challenge is that neutralizing antibodies should be rigorously tested in animal and cell culture models to confirm that they can neutralize the SARS-CoV-2 disease infection (Shin et al., 2019; Keck et al., 2019; Dhama et al., 2020b). The alternate strategy of generating the neutralizing antibodies against $\mathrm{S}$ protein is to immunize large animals like sheep, goat, cow and horse and purify the polyclonal antibodies from these animals. Monoclonal antibodies can be used as potent bio-therapeutics in the form of passive immunotherapy to neutralize the SARS-CoV-2 and to control the harmful outcomes of COVID-19 (Shanmugaraj et al., 2020). These strategies may prove to be beneficial in the condition of an outbreak since they have many advantages, such as simplifying production and manufacturing. For shorter treatment strategy, this could quickly help in SARS-CoV-2 outbreak.

For the time being, immunoglobulin $\mathrm{G}$ has been administered in COVID-19 critical patients as therapy (Liu et al., 2020b, 2020c). FcR has a role in pulmonary inflammation; hence blocking of FcR activation can reduce inflammatory damage in COVID-19. Thus intravenous use of immunoglobulins can prove helpful in the therapy of SARS-CoV-2 induced pulmonary inflammation (Fu et al., 2020).

\subsection{Oligonucleotides targeting SARS-CoV-2 RNA genome}

Apart from targeting S-protein of the nCoV-2019 virus using neutralizing antibodies, targeting of viral genomes could be other option to reduce the infectivity by degrading its genome. Recently, the RNA genome of the nCoV-2019 virus has been published (Gen Bank: MN908947.3). GS-5734, a nucleotide prodrug, showed broad-spectrum anti-coronavirus activity against bat $\mathrm{CoV}$, pre-pandemic bat $\mathrm{CoV}$, and existing human $\mathrm{CoV}$ in vitro and over primary human lung epithelial cell cultures and was found promising for treating epidemic and zoonotic coronaviruses of the near future (Sheahan et al., 2017). The siRNA or antisense oligonucleotides (ASO) can be used to combat the virus by targeting its genome (Qureshi et al., 2018).

Nevertheless, there are a few challenges associated with these methods, such as conserved RNA sequence in the genome of coronaviruses is still not known. Since the conserved sequences are essential in siRNA targeting to avoid viral escape from the oligonucleotides targeting strategy. Second, the delivery of oligonucleotides (siRNA and ASO) would be very challenging. Lipid nanoparticles technology can mediate the delivery of these oligonucleotides into the lungs (Youngren-Ortiz et al., 2016). Even though they were successful in the preclinical studies in animal models (Thi et al., 2015 and 2016), siRNA candidates in viral infections like Ebola have failed in clinical trials (Dunning J et al., 2016). Oligonucleoside analogues like remdesivir, which is a broad-spectrum antiviral drug, is proposed to have beneficial effects in COVID-19 therapy (Al-Tawfiq et al. 2020; Lu, 2020). Remdesivir and chloroquine have been reported to effectively inhibit SARS-CoV-2 in vitro (Wang et al. 2020c). They were able to block virus infection at low concentration (micromolar) and showed a high selectivity index (Rothan and Byrareddy, 2020; Wang et al. 2020c). 


\subsection{Passive antibody transfer}

One of the most effective and traditional tools used in most of the infectious outbreaks is the use of serum of patients who just recovered from the active viral infection to treat patients who contract in future (Mire et al., 2016). Patients recovered from active viral infections develop a polyclonal immune response to different antigens of SARS-CoV-2 as they neutralize active viral infections and hence convalescent-phase plasma can be used as a therapeutic alternative (Chan et al., 2015). Passive immunotherapy in the form of convalescent serum tested in MERS-CoV infected mice either as prophylactic or in therapeutic form both showed good results and supported the use of dromedary immune serum in preventing MERS-CoV infection (Zhao et al., 2015). Patients who have 100\% recovery from the novel coronavirus infection, can simply donate their plasma to treat the infected patients (Mire et al., 2016; Marano et al.,2016). The same strategy of convalescent serum was used during the Ebola virus outbreak in 2014-2015 (Kraft et al., 2015). Plasmaderived from the patients who recovered from the disease has also been used as therapy (Jin et al. 2020). $\alpha$-interferon atomization inhalation has been weakly recommended at a dose of 5 million U per time for adults in sterile injection water, twice a day (Jin et al. 2020). Similarly, interferon therapy has also been used; however, it aggravated pathology (Rothan and Byrareddy, 2020).

\subsection{Drug repurposing using available antivirals}

Drug repurposing is a promising, fast and cost-effective method that can overcome traditional de novo drug discovery and development challenges of targeting various diseases and disorders. Drug repurposing, the process of identifying new uses for the existing or candidate drugs is an effective strategy for drug discovery in multiple diseases, including infectious viral diseases. In combating the nCoV-2019 viral outbreak, use of already approved small drug molecules could inhibit the biological aspects of viral life cycle like replication, transcriptions, host protein interaction, boosting immunity, among others. Viral polymerase and protease inhibitors of HIV and hepatitis $\mathrm{C}$ virus are two potential antiviral regimens which can be repurposed against 2019-nCoV (Tsai et al., 2006; Anderson et al., 2009). During the SARS outbreak, HIV protease inhibitors like lopinavir and ritonavir had positive efficacy (Chu et al., 2004). In vitro and in vivo (over rhesus macaque) experiments suggested that combined therapeutic regimen of lopinavir/ritonavir alone or in combination with recombinant interferon- $\beta 1 \mathrm{~b}$ (IFN- $\beta 1 \mathrm{~b}$ ) have been found useful in treating MERS-CoV infection (Falzarano et al., 2013; Chan et al., 2015; Arabi et al., 2018). Hence, these are being explored as repurposed drugs against SARS-CoV-2 to treat COVID-19 (Wang et al., 2020d). The study demonstrated that combination of remdesivir (RDV) and interferon beta (IFN $\beta$ ) had better anti-viral efficacy as compared to combined formula of lopinavir and ritonavir in treating MERS-CoV infections (Sheahan et al., 2020).

Since the novel coronavirus belongs to the same category of SARS, repurposing of HIV drugs against novel coronavirus could give positive efficacy. Lopinavir may have some prospects in COVID-19 therapy as has been in the SARS, and MERS therapy; however, an extensive evaluation is required (Yao et al. 2020). Efficacy of remdesivir against SARS-CoV2 is under testing by Gilead Sciences (NASDAQ-GILD) pharmaceutical company 
(https://www.fool.com/investing/2020/03/04/is-gilead-sciences-the-best-buy-in-thecoronavirus.aspx). National Health Commission of the People's Republic of China has advocated the inclusion of chloroquine phosphate for the cure of COVID-19 patients, in its revised guidelines for the prevention, diagnosis, and treatment of pneumonia developed due to COVID-19 infection in the vast populous country (Gao et al., 2020; Lin and Li, 2020). Future research could continue to screen currently clinically available small molecular antiviral drugs in tissue culture models to identify candidate drugs to combat the novel coronavirus infection.

The pangolin $\mathrm{CoV}$ and SARS-CoV-2 are more than 92\% similar at amino acid levels. Thus, using pangolin coronavirus as a model three drugs namely, cepharanthine (CEP), selamectin, and mefloquine hydrochloride were observed to possess anti-SARS-CoV-2 activity with complete blocking of cell cytopathic effects (Fan et al., 2020).

Chen et al. (2020a) have used oseltamivir $(75 \mathrm{mg})$, lopinavir $(500 \mathrm{mg})$, ritonavir (500 mg) per os twice daily followed by ganciclovir $(0.25 \mathrm{~g})$ intravenously for 3-14 days in COVID-19 infected patients and they have shown safety hence can be considered as treatment options (Chen et al. 2020a). EIDD-2801 compound has proven effective against influenza viruses and can be evaluated against SARS-CoV-2 as well (Toots et al. 2019).

\subsection{Anti-viral proteases}

Rolf Hilgenfeld, a renowned structural biologist in the University of Lubeck, Germany has developed two compounds containing viral proteases and is intended to visit Wuhan, China at the peak of SARS-CoV-2 epidemic to test the clinical efficacy of these compounds in animals so that can use them for the treatment of COVID-19 patients suffering presently and in any future coronavirus outbreak (Cyranoski, 2020).

Anti-coronavirus protease activity was exhibited by the lopinavir (LPV), and it is proposed as a treatment option for ongoing COVID-19 infection (Yao et al., 2020). Further, a novel vinylsulfone protease inhibitor suggested treating patients suffering from the 2019-nCoV. That would help in the development of broad-spectrum anti-coronaviral agents for future epidemics (Morse et al., 2020). Recently, a breakthrough in search of antivirals came with the elucidation of SARS-CoV-2 main protease (Mpro) structure. The same could be exploited globally to design some novel drug candidates. Lately, a Deep Docking (DD) platform was used for structure-based virtual screening of nearly 1.3 billion molecules with potential of 1,000 putative ligands for SARS-CoV-2 Mpro protein (Ton et al., 2020).

\subsection{Blocking Coronavirus receptors like ACE2}

It is already known that ACE2 is a crucial player in the coronavirus infection by promoting cell entry (Hoffmann et al., 2020). The metallopeptidase, ACE2, has been identified as a functional receptor for SARS-CoV (Li et al., 2003) and a potent receptor for SARS-CoV-2 (Zhou et al., 2020). ACE2 is an important drug target for the treatment of cardiovascular and kidney diseases, and. Recently, Lei et al. (2020) demonstrated the potential of ACE2 based therapeutics against SARS-CoV-2, which could further be exploited alone or in combination, 
and they elucidate the molecular mechanisms of their potent and broad neutralizing activity. These ACE2 fusion proteins could be used for diagnosis and as research reagents in the development of vaccines and inhibitors. ACE2 and AT1R (angiotensin receptor one blocker) molecules such as losartan as inhibitors of the renin-angiotensin system (RAS) could be a useful therapeutic option in reducing the lung inflammation and treating pneumonia in COVID-19 patients (Gurwitz, 2020; Sun et al., 2020). The virus attachment through spike glycoprotein (S) to ACE2 receptors and subsequent priming of $\mathrm{S}$ protein by the host cell serine protease TMPRSS2 has been exploited as therapeutic targets. In this context, the role of TMPRSS2 protease in SARS-CoV-2 replication has been reported further supporting their probable role in the development of an active therapeutic agent (Matsuyama et al., 2020). The TMPRSS 2 inhibitor proved useful in blocking the virus entry and could work as a therapeutic option (Hoffmann et al., 2020).

\subsection{Combination therapy}

Rothan and Byrareddy (2020) have recommended the application of broad-spectrum antivirals like lopinavir/ritonavir, neuraminidase inhibitors, peptide (EK1), RNA synthesis inhibitors for the time being till specific antivirals are evaluated. Chen et al. (2020a) have used oseltamivir, lopinavir, ritonavir, ganciclovir in COVID-19 infected patients with excellent results however the combination of antiviral drugs is believed to be controversial (Jin et al. 2020). Other medications used are antibiotics (cephalosporins, quinolones, carbapenems, tigecycline against methicillin-resistant Staphylococcus aureus, linezolid, moxifloxacin or levofloxacin, azithromycin or amoxicillin and antifungal drugs), corticosteroids (prednisolone, dexamethasone), antipyretics (ibuprofen), anticoagulants (heparin) (Chen et al., 2020a; Jin et al., 2020; Rothan and Byrareddy, 2020; Zhang et al., 2020c). Huang et al. (2020) used antibiotics, methylprednisolone corticosteroid (40-120 mg per day), and oseltamivir (orally $75 \mathrm{mg}$ twice daily) in COVID-19 patients along with oxygen support. However, the use of antibiotics should be taken care as patients may not always develop bacterial complications (Du et al., 2020). Other trials involved the use of lopinavirritonavir and interferon- $\alpha$ 2b in COVID-19 patients (Anonymous 2020; Habibzadeh and Stoneman 2020). National Health Commission of China recommended combination of Ribavirin and interferon- $\alpha$ as a treatment regimen for COVID-19 in its fifth edition; however, the efficacy of Remdisivir and Ritonavir/Lopinavir needs to be determined by randomized controlled trial (Du et al., 2020). Rigorous preclinical and clinical both kind of trials are required before commencement of commercialization of combination therapy against COVID-19 (Li et al., 2020d).

Arbidol, an effective antiviral against SARS-CoV in combination with antibiotics (moxifloxacin or levofloxacin, nemonoxacin, linezolid, azithromycin or amoxicillin), corticosteroids and oxygen therapy has been used in COVID-19 therapy (Zhang et al. 2020c). Corticosteroids have been routinely used for the treatment of Th1 and Th2 induced lung injury reported in COVID-19 (Huang et al., 2020). Conventional Chinese drugs like ShuFengJieDu and Lianhuaqingwen were also used in the treatment of COVID-19, but their efficacy needs to be determined ( $\mathrm{Lu}, 2020)$. In contrast to this, WHO has indicated that currently no effective treatment for SARS-CoV-2 is known and use of different antibiotics, antiviral drugs, traditional Chinese drugs, corticosteroids like glucocorticoid and their 
combinations are not recommended before clinical trials as their efficacy is not known and might be detrimental to COVID-19 patients (Xiao et al., 2020; WHO, 2020d). Besides, to manage the hypoxia in the COVID-19 patients' ventilation and salvage therapy is reported beneficial. An $\alpha$-glucan-based mushroom extract, i.e. AHCC has been reported to be used as an immunostimulant for animals and humans affected by viral infections like the influenza virus, West Nile virus, hepatitis virus, herpes virus, papillomavirus and HIV. In this context, AHCC may be used in the prevention of COVID-19 after evaluation of its efficacy against SARS-CoV-2 (Di Pierro et al., 2020). For safe and successful treatment of severe respiratory illness in infants and children, probability of atelectasis due to invasive or non-invasive ventilation support and risks of oxygen toxicity must be taken into account (Marraro et al., 2020).

An overview of developing COVID-19 therapeutics and drugs is illustrated in Figure 1.

\section{COVID-19 Vaccines}

Appropriate preventive measures, as advised by WHO and CDC, must be implemented in order to delay the spread of COVID-19 so that health workers, healthcare departments, research and development wing and the government will get some time to design and test the targeted vaccines and therapeutics (Jernigan and CDC COVID-19 response team, 2020). Currently, there are no specific vaccines available against COVID-19 (Ahmed et al. 2020; Habibzadeh and Stoneman, 2020; Shang et al., 2020). Attempts are being made for the development of safe and effective prophylactic strategies (CDC, 2020; Shang et al. 2020). The earliest possibility is convalescent sera. Convalescent sera from the persons who recovered from the COVID-19 attack can be used as an immediate therapy (Casadevall and Pirofski 2020). Other sources of such sera can be genetically engineered animals, e.g. cows (Beigel et al. 2018). This serum contains immunoglobulins that can provide passive immunity. These antibodies can help in neutralization of SARS-CoV-2 or can help in antibodydependent cellular cytotoxicity, and phagocytosis (Casadevall and Pirofski 2020).

In search of suitable vaccine against SARS-CoV-2, mRNA-based vaccine (mRNA-1273) by Moderna (NASDAQ: MRNA) and INO-4800 as a vaccine by other company such as Inovio pharmaceuticals (NASDAQ-INO) are being developed and they will soon undergo clinical trials (Dhama et al., 2020b; https://www.fool.com/investing/2020/03/12/coronavirus-vaccinecandidates-could-enter-the-cli.aspx). In this context, a joint effort is made by Oxford University and Rocky Mountain Laboratories to develop a chimpanzee adenovirus vectored vaccine (NIAID, 2020). A vaccine made by Moderna Therapeutics is sent to the NIAID for a clinical trial which is anticipated by the end of April 2020 (https://www.livescience.com/uscoronavirus-vaccine-trial-recruiting.html). Additionally, a vaccine candidate expressing $\mathrm{S}$ protein of SARS-CoV-2 using mRNA vaccine platform technology is expected to hit clinical trial in the coming months (NIAID. 2020). Targeting spike proteins of CoV may have a role in vaccines and therapeutics as they induce highly potent neutralizing antibodies and are involved in host receptor binding and pathogenesis (He et al., 2004; Wang et al., 2016). Targeting spike glycoprotein (S glycoprotein) in SARS-CoV-2 can be useful (Habibzadeh and Stoneman, 2020). However, multiple efforts to develop vaccines against SARS-CoV-2 have been made but not reach a commercial level and could excel only to the pre-clinical 
levels until the preparation of the manuscript. Recently, WHO released a list of 35 vaccine candidates under pre-clinical level grouped into five major groups like live attenuated virus vaccines, DNA vaccines, non-replicating viral vector vaccines, replicating viral vector vaccines, and subunit vaccines (WHO, 2020e).

The other modes of vaccine development are the utilization of either the virus itself or its part for developing whole organism-based vaccines or subunit vaccines. These include attenuated or inactivated vaccines using cultured SARS-CoV-2 that can be attenuated by passaging or inactivated by physical and chemical methods such as UV light, formaldehyde, and $\beta$ propiolactone (Shang et al. 2020). However, these may have limitations of infectivity, reversion to pathogenicity, and disease-causing potential (Roper and Rehm, 2009).

Exploration of vaccine candidates of SARS-CoV-2 is essential for the development of specific vaccines (Habibzadeh and Stoneman, 2020; Shang et al., 2020) and the research and development are already being initiated (WHO, 2020e). A set of epitopes of SARS-CoV-2 have been screened, immune targeting of these epitopes can protect against this novel coronavirus and hence can provide experimental platforms for the development of vaccines (Ahmed et al. 2020). Identification of putative protective antigen/peptide from SARS-CoV-2 is essential for the development of subunit vaccines (Shang et al. 2020). The timely revealing of genome sequences is proving beneficial for subunit vaccine development (Wu et al. 2020b; Chan et al. 2020a). Structural proteins of SARS-CoV-2 including envelope (E), membrane $(\mathrm{M})$, nucleocapsid $(\mathrm{N})$, and spike (S) are being explored as antigens for subunit vaccine development (Chan et al. 2020a; Shang et al. 2020). Ahmed et al. (2020) have explored a set of $\mathrm{T}$ and $\mathrm{B}$ cell epitopes derived from Spike $(\mathrm{S})$ and nucleocapsid $(\mathrm{N})$ proteins mapping identically to SARS-CoV-2, and no mutations have been noted in these epitopes in 120 genome sequences hence can serve as vaccine candidates for the development of subunit vaccines.

Recently, antigenicity, along with structure and function of spike glycoprotein, especially of linear epitope S2 subunit of SARS-CoV-2 has been evaluated (Walls et al. 2020). Neutralizing antibodies have been raised against S2 subunit of SARS-CoV-2 that cross-react and neutralize both SARS-CoV-2 and SARS-CoV (Walls et al. 2020), hence, can be explored as candidates for subunit vaccines. Subunit vaccines have limitations of low immunity, the requirement of adjuvants and sometimes inefficient protective immunity while as DNA and mRNA based vaccines are more accessible and quick to clinical trials recombinant vaccines (Shang et al. 2020). Viral-vector based vaccines can be constructed and used without adjuvant. These vaccines are possible only when the antigens having neutralizing epitopes are explored (Shang et al. 2020). Mutated SARS-CoV-2, especially with altered E protein, can be exploited as a recombinant vaccine as $\mathrm{N}$ protein is conserved across CoVs hence not a suitable vaccine candidate (Gralinski and Menachery 2020; Shang et al. 2020).

The vaccine based on S2 protein subunit of the spike glycoprotein $(S)$ that helps in receptor binding and entry can have broad-spectrum antiviral effects as it is conserved in SARS-CoV2 (Chan et al. 2020a; Gralinski and Menachery 2020; Shang et al. 2020). Targeting S1 protein 
of SARS-CoV-2 can prevent virus entry and hence a strategy for controlling viral infection (Shang et al. 2020). Targeting S protein can both develop both cellular and humoral immunity by inducing neutralizing antibodies and by developing protective cellular immunity (Shang et al. 2020). Full-length S protein (Bukreyev et al. 2004), receptor-binding domain (RBD) (Song et al. 2019) of SARS-CoV have shown vaccine potential and can be explored in SARS-CoV-2 (Shang et al. 2020). Similarly, S1 subunit of spike protein in SARS-CoV-2 can be explored for antibody production hence prophylactic and therapeutic target (Chan et al. 2020a). Both aerosol or oral routes need to be explored as possible modes of administration (Shang et al. 2020).

DNA vaccines, chimeric viral vaccines, and membrane vesicle-vaccines are other probable options (Shang et al. 2020). An mRNA based vaccine by Moderna ${ }^{\circledR}$ is believed to develop antibodies against spike proteins of SARS-CoV-2, and a batch of vaccine has been delivered to the National Institute of Allergy and Infectious Diseases. This was developed 42 days after DNA sequence of SARS-CoV-2 was disclosed. Johnson and Johnson's ® is also working on the development of vaccines against COVID-19. Antibody-based treatment is being evaluated by Eli Lilly ${ }^{\circledR}$ and AbCellera ${ }^{\circledR}$. GlaxoSmithKline ${ }^{\circledR}$ has produced a pandemic vaccine adjuvant platform that it is partnering with other institutes and companies for use in COVID-19 vaccine candidates. Vaccine candidate INO-4800 is being evaluated by Inovio Pharmaceuticals®. Recombinant DNA vaccines are being studied by Sanofi® (Forbes, 2020). https://www.forbes.com/sites/alexknapp/2020/03/13/coronavirus-drug-update-the-latest-infoon-pharmaceutical-treatments-and-vaccines/.

As per recommendations of $\mathrm{CDC}$, researchers engaged in diagnosis and clinicians involved in the treatment of COVID-19 infected patients must wear all personal protective equipment including gloves, masks, goggles or face shield (Patel et al., 2020). Besides, due to short supply and unawareness of general public surgical masks are in extensive use which may only reduce the spread to some extent but not prevent the acquisition of SARS-CoV-2. Moreover, high filtration N95 masks along with PPE must be used by healthcare workers while attending patients to avoid nosocomial infection (Xiao et al., 2020).

Though the outbreaks are spreading worldwide healthcare workers caring for COVID-19 patients and other close contacts, as well as immunocompromised individuals are under high risk (CDC, 2020; Rohde, 2020; Yang et al., 2020a). Surprisingly, pregnancy-associated immunosuppression is reported beneficial for the mother as far as the severity of SARS-CoV2 infection is concerned possibly due to protection of lungs from cytokine storm brought by the immune system to counter the infectious agent (Who is getting sick... statnews.com/2020/03/03/who-is-getting-sick-and-how-sick-a-breakdown-of coronavirus risk-by-demographic-factors/).

Several measures were taken and still on to curb the disease, but no acclaimed antiviral or vaccines are available till date as researchers are at large, for which purpose researchers are working day and night as discussed above, and hopefully, appropriate proven vaccines and 
therapeutics would be available soon (Dhama et al., 2020b; Hui et al., 2020; Lai et al., 2020; Rodriguez-Morales et al., 2020b).

An overview of designing and developing COVID-19 vaccines is depicted in Figure 2.

\section{Patents on successful methodologies on various aspects of coronaviruses}

Global research focuses on coronavirus infections, especially the recently happened outbreaks of SARS, MERS and the most newly COVID-19. This involves exploration of diagnostics, prophylactics and therapeutics. Accordingly, patenting of successful methodologies has gained immense importance, safeguarding the interests of scientists and institutions. Various patents are being filed, and many approved on diagnostic, prophylactic and therapeutic aspects of coronaviruses and their diseases, especially SARS-CoV caused by SARS, MERS-CoV caused by MERS and the most newly SARS-CoV-2 caused COVID-19. As per one study, around $80 \%$ of patents are related to therapeutics, $35 \%$ for vaccines and $28 \%$ for diagnostics agents or methods (Liu et al. 2020c). Similarly, on MERS, more than 100 patents are published on therapeutics, and more than 50 on diagnostics and prophylactics (Liu et al. 2020c). These patents cover a range of research areas.

Table 2 provides details about the various fields and research areas for which patents have been applied and granted. These areas include developing novel, rapid, and specific diagnostics which are cheap and readily available (Liu et al. 2020c; Shenliang, 2016; Van Der Hoek 2007; Wei et al. 2016). For this purpose, exploration of novel methods or techniques is being elucidated that can be transformed into diagnostic technology. Further, identifying diagnostic markers are vital. Similarly, for the treatment purpose, novel drugs or therapeutic agents are being explored (Liu et al. 2020c). These need to be effective against coronaviruses, including SARS-CoV, MERS-CoV and SARS-CoV-2 (Chang et al., 2017; Emma et al. 2018; Liu et al., 2020c). These can be viral protease inhibitors (Emma et al. 2018), enzyme inhibitors (Kim et al. 2017), antivirals (Radtke et al. 2019; Shenliang, 2016), immunomodulators (Jordi et al. 2019), and treatment adjuvants (Adams and Lian 2020). This is the primary class which has attracted most of the patents (Liu et al. 2020c). Either a drug target is located or a direct antiviral compound, molecule or agent is established, or an indirect immunomodulator that raises the immune response against virus is identified as shown in Table 2. Vaccines which are the main backbone for the prevention strategies and are mostly lacking especially for novel coronaviruses have shown immense research prospects and are attracting a sufficient number of patents as shown in Table 2 (Liu et al. 2020c). Exploring novel vaccine candidates, targeting appropriate antigens, evaluating immune responses and transformation into a safe, effective and potent vaccine are some of the areas on which patents have been published (Bickerton et al. 2017; Sutter et al. 2016; Johnson et al. 2017). They can be univalent targeting a single pathogen (species/strain) (Brownlie et al. 2012; Sutter et al., 2016) or multivalent targeting many at a time (Johnson et al. 2017). Presently no specific therapeutics or vaccines are available against SARS-CoV-2. Since there is some degree of genomic and structural identity hence therapeutics active against SARS-CoV or MERS-CoV or other broad-spectrum antivirals (e.g. remdesivir, chloroquine) are being explored for SARS-CoV-2. Identification of specific therapeutic targets and vaccines candidates will enable developing of specific and potential drugs or vaccines that can prove useful in the prevention and control of SARS-CoV-2 (Liu et al. 2020c). 


\section{Conclusion and Future Perspectives}

Currently, SARS-CoV-2 outbreak has taken a disastrous turn with high toll rates alone in China itself, most likely the infection is spreading across the globe. There are no licensed vaccines or therapeutic agents (i.e., antivirals and monoclonal antibodies) indicated for this coronavirus prevention or treatment. However, researchers are working to develop countermeasures. Several vaccine candidates for both SARS-CoV-2 are in early clinical trials. This review is an accumulative hub of the latest knowledge and out comings of all novel approach to tackle this deadly disease. Validated and clinically proven therapeutic measures are in great need at this hour of crisis to ensure global safety and on stopping this pandemic before it leads to distressing global outbreaks.

Under the current COVID-19 pandemic scenario the global threats are increasing, more countries are being predisposed, and new outbreaks are being reported, increasing the number of infected cases and risks to non-infected persons - this necessitates timely intervention for appropriate management of affected ones and prevention of threats to healthy ones. Nonavailability of specific antivirals against COVID-19 is causing heavy tolls in infected persons. Utilization of conventional therapies as supportive treatment though helps in managing severity but is proving ineffective on a long term basis as the overall mortality is changing significantly daily. Non-specific antiviral therapy by oseltamivir, ganciclovir; antibacterial therapy by moxifloxacin, ceftriaxone, azithromycin; and glucocorticoid therapy is being improvised by adding broad-spectrum antivirals such as remdesivir, chloroquine, or lopinavir/ritonavir. Passive therapy by $\alpha$-interferon atomization inhalation, immunoglobulin $\mathrm{G}$ therapy, or plasma therapy is proving beneficial.

However, there is a dire need for development and evaluation of specific antivirals against COVID-19. There have been attempts for exploring the applicability of already existing antivirals, potential antivirals or combination thereof along with supportive medicines; however, the focus should be on designing and adopting safe and effective modalities against SARS-CoV-2. These include developing neutralizing antibodies, oligonucleotides targeting SARS-CoV-2RNA genome, passive antibody transfer, drug repurposing using available antivirals, anti-viral proteases, blocking coronavirus receptors like ACE2, targeting spike proteins, and combination therapies.

Alternative measures like neutralizing antibodies, oligonucleotides, passive antibody transfer and drug repurposing can bring a revolutionary change until the core researchers are busy finding the specific target to curb the SARS-CoV-2 which can be time taking and still at large.

\section{Author contributions}

All the authors substantially contributed to the conception, design, analysis and interpretation of data, checking and approving the final version of the manuscript, and agree to be accountable for its contents. AAR, SHA, RS and SH initiated this review compilation; RT, SKP, MP, MIY, DKB, YSM and KD updated various sections. SKP and MP developed 
Figure and MIY developed Table of Patents. KD and AJR-M reviewed advances in therapeutics and vaccines, overviewed and edited final.

\section{Funding}

This compilation is a review article written, analyzed and designed by its authors and required no substantial funding to be stated.

\section{Acknowledgement}

None.

\section{Conflicts of interest}

All authors declare that there exist no commercial or financial relationships that could in any way lead to a potential conflict of interest.

\section{References}

1. Adams J and Lian Y. 2020. Novel Compounds. US20200002370A1

2. Ahmed SF, Quadeer AA, McKay MR. Preliminary Identification of Potential Vaccine Targets for the COVID-19 Coronavirus (SARS-CoV-2) Based on SARS-CoV Immunological Studies. Viruses. 2020;12(3):E254. doi: 10.3390/v12030254.

3. Al-Tawfiq JA, Al-Homoud AH, Memish ZA. Remdesivir as a possible therapeutic option for the COVID-19. Travel Med Infect Dis. 2020:101615. doi: 10.1016/j.tmaid.2020.101615.

4. Anand K, Ziebuhr J, Wadhwani P, Mesters JR, Hilgenfeld R. Coronavirus main proteinase (3CLpro) structure: basis for design of anti-SARS drugs. Science. 2003 Jun 13;300(5626):1763-7. doi: 10.1126/science.1085658.

5. Anderson J, Schiffer C, Lee SK, et al.: Viral protease inhibitors. Handb Exp Pharmacol. 2009; 189:85-110.

6. Anonymous 2020; A randomized, open-label, blank-controlled trial for the efficacy and safety of lopinavir-ritonavir and interferon-alpha $2 \mathrm{~b}$ in hospitalization patients with novel coronavirus infection. Available from www.chictr.org.cn/showprojen.aspx?proj=48684 (Accessed January 31, 2020).

7. Arabi YM, Alothman A, Balkhy HH, Al-Dawood A, AlJohani S, Al Harbi S, Kojan S, Al Jeraisy M, Deeb AM, Assiri AM, Al-Hameed F, AlSaedi A, Mandourah Y, Almekhlafi GA, Sherbeeni NM, Elzein FE, Memon J, Taha Y, Almotairi A, Maghrabi KA, Qushmaq I, Al Bshabshe A, Kharaba A, Shalhoub S, Jose J, Fowler RA, Hayden FG, Hussein MA; And the MIRACLE trial group. Treatment of Middle East Respiratory Syndrome with a combination of lopinavir-ritonavir and interferon- $\beta 1 \mathrm{~b}$ (MIRACLE trial): study protocol for a randomized controlled trial. Trials. 2018;19(1):81. doi: 10.1186/s13063-017-2427-0.

8. Bassetti M, Vena A, Giacobbe DR. The novel Chinese coronavirus (2019-nCoV) infections: Challenges for fighting the storm. Eur J Clin Invest. 2020;50(3):e13209. doi: 10.1111/eci.13209.

9. Beigel JH, Voell J, Kumar P, Raviprakash K, Wu H, Jiao JA, Sullivan E, Luke T, Davey RT Jr. Safety and tolerability of a novel, polyclonal human anti-MERS coronavirus antibody produced from transchromosomic cattle: a phase 1 randomised, double-blind, single-doseescalation study. Lancet Infect Dis. 2018;18(4):410-418. doi: 10.1016/S1473-3099(18)300021. 
10. Bickerton E, Keep S, Britton P. 2017. Attenuated infectious bronchitis virus. WO2017129975A1.

11. Bickerton E, Keep S, Britton P. 2018. Coronavirus. US10130701B2.

12. Blatt LM, Beigelman L, Symons JA, Smith DB. 2019. Substituted nucleosides, nucleotides and analogs thereof. US10307439B2.

13. Bonus, Ulaboch, Schornack J, Lahaie S, Thomas 2019. Modular DNA binding domain and method of use. JP6508605B2

14. Brennan MB, Spiegel EK, Staerz UD, Wall C, Wheeler J, Maslanik WJ, Zhang X. 2017. Construction of fully-deleted adenovirus-based gene delivery vectors and uses thereof. US9719107B2.

15. Brownlie J, Chalker VJ, Erles K. 2012. Spike protein of canine respiratory coronavirus (crcv), polymerase and hemaglutinin / esterase. ES2384445T3.

16. Bukreyev A, Lamirande EW, Buchholz UJ, Vogel LN, Elkins WR, St Claire M, Murphy BR, Subbarao K, Collins PL. Mucosal immunisation of African green monkeys (Cercopithecus aethiops) with an attenuated parainfluenza virus expressing the SARS coronavirus spike protein for the prevention of SARS. Lancet. 2004;363(9427):2122-7. doi: 10.1016/S01406736(04)16501-X.

17. Casadevall A, Pirofski LA. The convalescent sera option for containing COVID-19. J Clin Invest. 2020:138003. doi: 10.1172/JCI138003.

18. Casadevall A, Pirofski LA. The Ebola epidemic crystallizes the potential of passive antibody therapy for infectious diseases. PLoS Pathog. 2015;11(4):e1004717. doi: 10.1371/journal.ppat.1004717.

19. Cascella M, Rajnik M, Cuomo A, Dulebohn SC, Di Napoli R. Features, Evaluation and Treatment Coronavirus (COVID-19). 2020 Mar 8. In: StatPearls [Internet]. Treasure Island (FL): StatPearls Publishing; 2020 Jan-.Available from: https://www.ncbi.nlm.nih.gov/books/NBK554776/.

20. CDC. 2020. Prevention \& Treatment. Available from www.cdc.gov/coronavirus/2019ncov/about/preventiontreatment.html (Accessed March 15, 2020).

21. Centers for Disease Control and Prevention. Human coronavirus types. January 10, 2020. (https://www.cdc.gov/ coronavirus/types.html). Accessed January 17, 2020.

22. Chan JF, Yuan S, Kok KH, To KK, Chu H, Yang J, Xing F, Liu J, Yip CC, Poon RW, Tsoi HW, Lo SK, Chan KH, Poon VK, Chan WM, Ip JD, Cai JP, Cheng VC, Chen H, Hui CK, Yuen KY. A familial cluster of pneumonia associated with the 2019 novel coronavirus indicating person-to-person transmission: a study of a family cluster. Lancet. 2020a;395(10223):514-523. doi: 10.1016/S0140-6736(20)30154-9

23. Chan JF, Kok KH, Zhu Z, Chu H, To KK, Yuan S, Yuen KY. Genomic characterization of the 2019 novel human-pathogenic coronavirus isolated from a patient with atypical pneumonia after visiting Wuhan. Emerg Microbes Infect. 2020b;9(1):221-236. doi: 10.1080/22221751.2020.1719902.

24. Chan JF, Yao Y, Yeung ML, Deng W, Bao L, Jia L, Li F, Xiao C, Gao H, Yu P, Cai JP, Chu H, Zhou J, Chen H, Qin C, Yuen KY. Treatment With Lopinavir/Ritonavir or Interferon- $\beta 1 b$ Improves Outcome of MERS-CoV Infection in a Nonhuman Primate Model of Common Marmoset. J Infect Dis. 2015;212(12):1904-13. doi: 10.1093/infdis/jiv392.

25. Chang K, Yunjeong KIM, Groutas WC. 2017. Small molecule therapeutic inhibitors against picornaviruses, caliciviruses, and coronaviruses. WO2017222935A1. 
26. Chen N, Zhou M, Dong X, Qu J, Gong F, Han Y, Qiu Y, Wang J, Liu Y, Wei Y, Xia J, Yu T, Zhang X, Zhang L. Epidemiological and clinical characteristics of 99 cases of 2019 novel coronavirus pneumonia in Wuhan, China: a descriptive study. Lancet. 2020a;395(10223):507-513. doi: 10.1016/S0140-6736(20)30211-7.

27. Chen Y, Liu Q, Guo D. Emerging coronaviruses: Genome structure, replication, and pathogenesis. J Med Virol. 2020b;92(4):418-423. doi: 10.1002/jmv.25681.

28. Chen Z, Bao L, Chen C, Zou T, Xue Y, Li F, Lv Q, Gu S, Gao X, Cui S, Wang J, Qin C, Jin Q. Human Neutralizing Monoclonal Antibody Inhibition of Middle East Respiratory Syndrome Coronavirus Replication in the Common Marmoset. $J$ Infect Dis. 2017;215(12):1807-1815. doi: 10.1093/infdis/jix209.

29. Chu CM, Cheng VC, Hung IF, Wong MM, Chan KH, Chan KS, Kao RY, Poon LL, Wong CL, Guan Y, Peiris JS, Yuen KY; HKU/UCH SARS Study Group. Role of lopinavir/ritonavir in the treatment of SARS: initial virological and clinical findings. Thorax. 2004;59(3):252-6. doi: 10.1136/thorax.2003.012658.

30. Ciaramella G, Bouchon A, Huang EYC. 2018. Nucleic acid vaccines. US9872900B2.

31. Corman VM, Eckerle I, Bleicker T, Zaki A, Landt O, Eschbach-Bludau M, van Boheemen S, Gopal R, Ballhause M, Bestebroer TM, Muth D, Müller MA, Drexler JF, Zambon M, Osterhaus AD, Fouchier RM, Drosten C. Detection of a novel human coronavirus by realtime reverse-transcription polymerase chain reaction. Euro Surveill. 2012;17(39):20285. doi: 10.2807/ese.17.39.20285-en.

32. Corti D, Zhao J, Pedotti M, Simonelli L, Agnihothram S, Fett C, Fernandez-Rodriguez B, Foglierini M, Agatic G, Vanzetta F, Gopal R, Langrish CJ, Barrett NA, Sallusto F, Baric RS, Varani L, Zambon M, Perlman S, Lanzavecchia A. Prophylactic and postexposure efficacy of a potent human monoclonal antibody against MERS coronavirus. Proc Natl Acad Sci U S A. 2015;112(33):10473-8. doi: 10.1073/pnas.1510199112.

33. Cotten M, Watson SJ, Kellam P, Al-Rabeeah AA, Makhdoom HQ, Assiri A, Al-Tawfiq JA, Alhakeem RF, Madani H, AlRabiah FA, Al Hajjar S, Al-nassir WN, Albarrak A, Flemban H, Balkhy HH, Alsubaie S, Palser AL, Gall A, Bashford-Rogers R, Rambaut A, Zumla AI, Memish ZA. Transmission and evolution of the Middle East respiratory syndrome coronavirus in Saudi Arabia: a descriptive genomic study. Lancet. 2013;382(9909):19932002. doi: 10.1016/S0140-6736(13)61887-5.

34. Cui J, Li F, Shi ZL. Origin and evolution of pathogenic coronaviruses. Nat Rev Microbiol. 2019;17(3):181-192. doi: 10.1038/s41579-018-0118-9.

35. Cyranoski D. This scientist hopes to test coronavirus drugs on animals in locked-down Wuhan. Nature. 2020;577(7792):607. doi: 10.1038/d41586-020-00190-6.

36. Dhama K, Karthik K, Khandia R, Chakraborty S, Munjal A, Latheef S K, Kumar D, Ramakrishnan M A, Malik Y S and Singh R. Advances in designing and developing vaccines, drugs, and therapies to counter Ebola virus. Frontiers in Immunology. 2018a. 9: 1803.

37. Dhama K, Karthik K, Khandia R, Munjal A, Tiwari R, Rana R, Khurana SK, Sana Ullah, Khan RU, Alagawany M, Farag MR, Dadar M, Joshi SK. Medicinal and therapeutic potential of herbs and plant metabolites / extracts countering viral pathogens - Current knowledge and future prospects. Curr Drug Metab. 2018b. 19(3):236-263. doi: $10.2174 / 1389200219666180129145252$.

38. Dhama K, Sharun K, Tiwari R, Dadar M, Malik YS, Singh KP, Chaicumpa W. COVID-19, an emerging coronavirus infection: advances and prospects in designing and developing 
vaccines, immunotherapeutics, and therapeutics. Hum Vaccin Immunother. 2020b:1-7. doi: 10.1080/21645515.2020.1735227.

39. Dhama K, Sharun K, Tiwari R, Sircar S, Bhat S, Malik YS, Singh KP, Chaicumpa W, Bonilla-Aldana DK, Rodriguez-Morales, AJ. Coronavirus disease 2019 - COVID19. Preprints. 2020a. 2020030001. doi: 10.20944/preprints202003.0001.v1

40. Dhama K, Verma AK, Rajagunalan S, Deb R, Karthik K, Kapoor S, Mahima, Tiwari R, Panwar PK, Chakraborty S. Swine flu is back again: a review. Pak J Biol Sci. 2012;15(21):1001-9. doi: 10.3923/pjbs.2012.1001.1009.

41. Dhama, K., Chakraborty, S., Tiwari, R., Kumar, A., Rahal, A., Latheef, S.K., Wani, M.Y. and Kapoor, S.. Avian/bird flu virus: poultry pathogen having zoonotic and pandemic threats - a review. J. Medical Sciences. 2013;13(5):301-315.

42. Dhama, K., Pawaiya RVS, Chakraborty S, Tiwari R, Saminathan M, Verma AK. Coronavirus Infection in Equines: A Review. Asian J. Anim. Vet. Adv, 2014. 9: p. 164-176.

43. Di Pierro F, Bertuccioli A, Cavecchia I. Possible therapeutic role of a highly standardized mixture of active compounds derived from cultured Lentinula edodes mycelia (AHCC) in patients infected with 2019 novel coronavirus. Minerva Gastroenterol Dietol. 2020. doi: 10.23736/S1121-421X.20.02697-5.

44. Dickey B, Evans S, Gilbert B, Markesich D, Scott B, Tuvim M. 2019a. Compositions and methods for treating viral infections through stimulated innate immunity in combination with antiviral compounds. US20190314497A1.

45. Dickey B, Evans S. Gilbert B, Markesich D, Scott B, Tuvim M. 2019b. Compositions and methods for treating viral infections through stimulated innate immunity in combination with antiviral compounds. US10286065B2.

46. Dong E, Du H, Gardner L. An interactive web-based dashboard to track COVID-19 in real time. Lancet Infect Dis. 2020;19:S1473-3099(20)30120-1. doi: 10.1016/S14733099(20)30120-1.

47. DST and Health Commission China. Expert consensus on chloroquine phosphate for the treatment of novel coronavirus pneumonia. Chinese Journal of Tuberculosis and Respiratory diseases. 2020; 43(3): 185-88.10.3760/cma.j.issn.1001-0939.2020.03.009

48. Du B, Qiu HB, Zhan X, Wang YS, Kang HYJ, Li XY, Wang F, Sun B, Tong ZH. [Pharmacotherapeutics for the new coronavirus pneumonia]. Zhonghua Jie He He Hu Xi Za Zhi. 2020;43(3):173-176. Chinese. doi: 10.3760/cma.j.issn.1001-0939.2020.03.005.

49. Du L, He Y, Zhou Y, Liu S, Zheng BJ, Jiang S. The spike protein of SARS-CoV--a target for vaccine and therapeutic development. Nat Rev Microbiol. 2009;7(3):226-36. doi: 10.1038/nrmicro2090.

50. Dubensky TW, Brockstedt JDG, Leong MLL, Bahjat KS. 2018. Methods and compositions using Listeria for enhancing immunogenicity by prime boost. US9878024B2.

51. Ellwanger JH, Chies JAB. Zoonotic spillover and emerging viral diseases - time to intensify zoonoses surveillance in Brazil. Braz J Infect Dis 2018;22(1):76-78. https://doi.org/10.1016/j.bjid.2017.11.003.

52. Emma S, St. John, Mesecar AD. 2018. Broad-spectrum non-covalent coronavirus protease inhibitors. S9975885B2.

53. Falzarano D, de Wit E, Rasmussen AL, Feldmann F, Okumura A, Scott DP, Brining D, Bushmaker T, Martellaro C, Baseler L, Benecke AG, Katze MG, Munster VJ, Feldmann H. Treatment with interferon- $\alpha 2 b$ and ribavirin improves outcome in MERS-CoV-infected rhesus macaques. Nat Med. 2013;19(10):1313-7. doi: 10.1038/nm.3362. 
54. Fan HH, Wang LQ, Liu WL, An XP, Liu ZD, He XQ, Song LH, Tong YG. Repurposing of clinically approved drugs for treatment of coronavirus disease 2019 in a 2019-novel coronavirus (2019-nCoV) related coronavirus model. Chin Med J (Engl). 2020. doi: 10.1097/CM9.0000000000000797.

55. Flahault A. Has China faced only a herald wave of SARS-CoV-2? Lancet. 2020.S01406736(20)30521-3. doi: 10.1016/S0140-6736(20)30521-3.

56. Forbes 2020. https://www.forbes.com/sites/alexknapp/2020/03/13/coronavirus-drug-updatethe-latest-info-on-pharmaceutical-treatments-and-vaccines/.

57. Francis JN, Redman JS, Kay MS. 2019. Methods and compositions related to inhibition of viral entry. US10406229B2.

58. Fu Y, Cheng Y, Wu Y. Understanding SARS-CoV-2-Mediated Inflammatory Responses: From Mechanisms to Potential Therapeutic Tools. Virol Sin. 2020. doi: 10.1007/s12250-02000207-4.

59. Galasiti Kankanamalage AC, Kim Y, Damalanka VC, Rathnayake AD, Fehr AR, Mehzabeen N, Battaile KP, Lovell S, Lushington GH, Perlman S, Chang KO, Groutas WC. Structureguided design of potent and permeable inhibitors of MERS coronavirus 3CL protease that utilize a piperidine moiety as a novel design element. Eur J Med Chem. 2018;150:334-346. doi: 10.1016/j.ejmech.2018.03.004.

60. Gao J, Tian Z, Yang X. Breakthrough: Chloroquine phosphate has shown apparent efficacy in treatment of COVID-19 associated pneumonia in clinical studies. Biosci Trends. 2020;14(1):72-73. doi: 10.5582/bst.2020.01047.

61. Gates B. Responding to Covid-19 - A Once-in-a-Century Pandemic? N Engl J Med. 2020. doi: 10.1056/NEJMp2003762.

62. Geall A, Ramsauer K, Otten G, Mand CW. 2019. Delivery of RNA to trigger multiple immune pathways. US20190343862A1.

63. Geller C, Varbanov M, Duval RE. Human coronaviruses: insights into environmental resistance and its influence on the development of new antiseptic strategies. Viruses. 2012;4(11):3044-68. doi: 10.3390/v4113044.

64. Gorbalenya AE, Baker SC, Baric RS, de Groot RJ, Drosten C, Gulyaeva AA, Haagmans BL, Lauber C, Leontovich AM, Neuman BW, Penzar D. Severe acute respiratory syndromerelated coronavirus: The species and its viruses-a statement of the Coronavirus Study Group.bioRxiv2020; 2020.02.07.937862; doi: 10.1101/2020.02.07.937862

65. Graham B, Kong WP, Modjarrad K, Wang L, Shi W, Joyce MG, Kanekiyo M, Mascola J. 2016. Middle East Respiratory Syndrome coronavirus immunogens, antibodies, and their use. WO2016138160A1.

66. Gralinski LE, Menachery VD. Return of the Coronavirus: 2019-nCoV. Viruses. 2020;12(2):E135. doi: 10.3390/v12020135.

67. Gray $\mathrm{S}$ and McCown T. 2019. AAV vectors targeted to the central nervous system.US20190365925A1.

68. Greenland JR, Michelow MD, Wang L, London MJ. 2020. COVID-19 Infection: Implications for Perioperative and Critical Care Physicians. Anesthesiology. doi: 10.1097/ALN.0000000000003303.

69. Gui M, Song W, Zhou H, Xu J, Chen S, Xiang Y, Wang X. Cryo-electron microscopy structures of the SARS-CoV spike glycoprotein reveal a prerequisite conformational state for receptor binding. Cell Res. 2017;27(1):119-129. doi: 10.1038/cr.2016.152. 
70. Guo YR, Cao QD, Hong ZS, Tan YY, Chen SD, Jin HJ, Tan KS, Wang DY, Yan Y. 2020. The origin, transmission and clinical therapies on coronavirus disease 2019 (COVID-19) outbreak - an update on the status. Mil Med Res. 7(1):11. doi: 10.1186/s40779-020-00240-0.

71. Gurwitz D. Angiotensin receptor blockers as tentative SARS-CoV-2 therapeutics. Drug Dev Res. 2020. doi: 10.1002/ddr.21656.

72. Habibzadeh P, Stoneman EK. The Novel Coronavirus: A Bird's Eye View. Int J Occup Environ Med. 2020;11(2):65-71. doi: 10.15171/ijoem.2020.1921.

73. He Y, Zhou Y, Liu S, Kou Z, Li W, Farzan M, Jiang S. Receptor-binding domain of SARS$\mathrm{CoV}$ spike protein induces highly potent neutralizing antibodies: implication for developing subunit vaccine. Biochem Biophys Res Commun. 2004;324(2):773-81. doi: 10.1016/j.bbrc.2004.09.106.

74. Hoffmann M, Kleine-Weber H, Schroeder S, Krüger N, Herrler T, Erichsen S, Schiergens TS, Herrler G, Wu NH, Nitsche A, Müller MA, Drosten C, Pöhlmann S. SARS-CoV-2 Cell Entry Depends on ACE2 and TMPRSS2 and Is Blocked by a Clinically Proven Protease Inhibitor. Cell. 2020:S0092-8674(20)30229-4. doi: 10.1016/j.cell.2020.02.052.

75. Holst PJ, Thomsen AR, Christensen JP. 2008. A nucleotide vaccine. WO2007062656A3.

76. https://www.businessinsider.in/science/news/the-genetic-code-of-the-wuhan-coronavirusshows-its-80-similar-to-sars-new-research-suggests-a-potential-way-to-neutralize-the-virus/articleshow/73918190.cms

77. https://www.fool.com/investing/2020/03/04/is-gilead-sciences-the-best-buy-in-thecoronavirus.aspx.

78. https://www.fool.com/investing/2020/03/12/coronavirus-vaccine-candidates-could-enter-thecli.aspx

79. Huang C, Wang Y, Li X, Ren L, Zhao J, Hu Y, Zhang L, Fan G, Xu J, Gu X, Cheng Z, Yu T, Xia J, Wei Y, Wu W, Xie X, Yin W, Li H, Liu M, Xiao Y, Gao H, Guo L, Xie J, Wang G, Jiang R, Gao Z, Jin Q, Wang J, Cao B. Clinical features of patients infected with 2019 novel coronavirus in Wuhan, China. Lancet. 2020;395(10223):497-506. doi: 10.1016/S01406736(20)30183-5.

80. Hui DS, I Azhar E, Madani TA, Ntoumi F, Kock R, Dar O, Ippolito G, Mchugh TD, Memish ZA, Drosten C, Zumla A, Petersen E. The continuing 2019-nCoV epidemic threat of novel coronaviruses to global health - The latest 2019 novel coronavirus outbreak in Wuhan, China. Int J Infect Dis. 2020;91:264-266. doi: 10.1016/j.ijid.2020.01.009.

81. Jernigan DB; CDC COVID-19 Response Team. Update: Public Health Response to the Coronavirus Disease 2019 Outbreak - United States, February 24, 2020. MMWR Morb Mortal Wkly Rep. 2020;69(8):216-219. doi: 10.15585/mmwr.mm6908e1.

82. Ji W, Wang W, Zhao X, Zai J, Li X. Homologous recombination within the spike glycoprotein of the newly identified coronavirus may boost cross-species transmission from snake to human. J Med Virol. 2020;92(4):433-440. doi:10.1002/jmv.25682.

83. Jia Z, Yan L, Ren Z, Wu L, Wang J, Guo J, Zheng L, Ming Z, Zhang L, Lou Z, Rao Z. Delicate structural coordination of the Severe Acute Respiratory Syndrome coronavirus Nsp13 upon ATP hydrolysis. Nucleic Acids Res. 2019;47(12):6538-6550. doi: 10.1093/nar/gkz409.

84. Jiang S, Du L, Zhou Y, Zhao G. 2018. Immunogenic composition for MERS coronavirus infection. US9889194B2.

85. Jin YH, Cai L, Cheng ZS, Cheng H, Deng T, Fan YP, Fang C, Huang D, Huang LQ, Huang Q, Han Y, Hu B, Hu F, Li BH, Li YR, Liang K, Lin LK, Luo LS, Ma J, Ma LL, Peng ZY, 
Pan YB, Pan ZY, Ren XQ, Sun HM, Wang Y, Wang YY, Weng H, Wei CJ, Wu DF, Xia J, Xiong Y, Xu HB, Yao XM, Yuan YF, Ye TS, Zhang XC, Zhang YW, Zhang YG, Zhang HM, Zhao Y, Zhao MJ, Zi H, Zeng XT, Wang YY, Wang XH; , for the Zhongnan Hospital of Wuhan University Novel Coronavirus Management and Research Team, Evidence-Based Medicine Chapter of China International Exchange and Promotive Association for Medical and Health Care (CPAM). A rapid advice guideline for the diagnosis and treatment of 2019 novel coronavirus (2019-nCoV) infected pneumonia (standard version). Mil Med Res. 2020;7(1):4. doi: 10.1186/s40779-020-0233-6.

86. Jin M, Tong Q. Rhabdomyolysis as Potential Late Complication Associated with COVID-19. Emerg Infect Dis. 2020;26(7). doi: 10.3201/eid2607.200445.

87. Johnson RF, Schnell M, Hensley LE, Wirblich C, Coleman CM, Frieman MB. 2017. Multivalent vaccines for rabies virus and coronaviruses. WO2017176596A1.

88. Jordi MF, John R, Nover BA, Abac C. 2019. Immunomodulation methods and compositions. JP2019206573A.

89. Jung IY, Lee H, Lee HY, Lee H. 2018. Microfluidic device for detecting target gene, method for manufacturing same, and method for detecting using same. AU2015340134B2.

90. Keck ZY, Wang Y, Lau P, Foung SKH. Isolation of HCV Neutralizing Antibodies by Yeast Display. Methods Mol Biol. 2019;1911:395-419. doi: 10.1007/978-1-4939-8976-8_27.

91. Kilianski A, Baker SC. Cell-based antiviral screening against coronaviruses: developing virus-specific and broad-spectrum inhibitors. Antiviral Res. 2014;101:105-12. doi: 10.1016/j.antiviral.2013.11.004.

92. Kim BK. 2016. Recombinant vaccine proteins.US20160339097A1.

93. Kim DY, Park MS, Cho DJ, Lee GY, Kim HY, Lee HU, Ahn CA, Bang HY, Song SE, Park JS. 2017. Use of radotinib for prevention or treatment of viral respiratory disease. WO2017010835A1.

94. Kraft CS, Hewlett AL, Koepsell S, Winkler AM, Kratochvil CJ, Larson L, Varkey JB, Mehta AK, Lyon GM 3rd, Friedman-Moraco RJ, Marconi VC, Hill CE, Sullivan JN, Johnson DW, Lisco SJ, Mulligan MJ, Uyeki TM, McElroy AK, Sealy T, Campbell S, Spiropoulou C, Ströher U, Crozier I, Sacra R, Connor MJ Jr, Sueblinvong V, Franch HA, Smith PW, Ribner BS; Nebraska Biocontainment Unit and the Emory Serious Communicable Diseases Unit. The Use of TKM-100802 and Convalescent Plasma in 2 Patients With Ebola Virus Disease in the United States. Clin Infect Dis. 2015;61(4):496-502. doi: 10.1093/cid/civ334.

95. Kyratsous C, Stahl N, Sivapalasingam S. 2019. Human Antibodies to Middle East Respiratory Syndrome - Coronavirus Spike Protein. US20190351049A1.

96. Lai CC, Shih TP, Ko WC, Tang HJ, Hsueh PR. Severe acute respiratory syndrome coronavirus 2 (SARS-CoV-2) and coronavirus disease-2019 (COVID-19): The epidemic and the challenges. Int J Antimicrob Agents. 2020;55(3):105924. doi: 10.1016/j.ijantimicag.2020.105924.

97. Lai MMC, Holmes KV. 2001 Coronaviridae: the viruses and their replication, in: Knipe, D.M. and Howley, P.M. (Eds.), Fields virology. Lippincott Williams \&Wilkins, Philadelphia, pp. 1163-1179.

98. Lei C, Fu W, Qian K, Li T, Zhang S, Ding M, Hu S. Potent neutralization of 2019 novel coronavirus by recombinant ACE2-Ig. bioRxiv. 2020. doi: https://doi.org/10.1101/2020.02.01.929976.

99. Li F. Structure, Function, and Evolution of Coronavirus Spike Proteins. Annu Rev Virol. 2016;3(1):237-261. doi: 10.1146/annurev-virology-110615-042301. 
100. Li W, Moore MJ, Vasilieva N, Sui J, Wong SK, Berne MA, Somasundaran M, Sullivan JL, Luzuriaga K, Greenough TC, Choe H, Farzan M. Angiotensin-converting enzyme 2 is a functional receptor for the SARS coronavirus. Nature. 2003;426(6965):450-4. doi: 10.1038/nature02145.

101. Li Z, Ge J, Yang M, Feng J, Qiao M, Jiang R, Bi J, Zhan G, Xu X, Wang L, Zhou Q, Zhou C, Pan Y, Liu S, Zhang H, Yang J, Zhu B, Hu Y, Hashimoto K, Jia Y, Wang H, Wang $\mathrm{R}$, Liu C, Yang C. Vicarious traumatization in the general public, members, and nonmembers of medical teams aiding in COVID-19 control. Brain Behav Immun. 2020a:S08891591(20)30309-3. doi: 10.1016/j.bbi.2020.03.007.

102. Li YC, Bai WZ, Hashikawa T. The neuroinvasive potential of SARS-CoV2 may be at least partially responsible for the respiratory failure of COVID-19 patients. J Med Virol. 2020b. doi: 10.1002/jmv.25728.

103. Li H, Wang YM, Xu JY, Cao B. Potential antiviral therapeutics for 2019 Novel Coronavirus. Zhonghua Jie $\mathrm{He} \mathrm{He} \mathrm{Hu} \mathrm{Xi} Z \mathrm{Za} Z$ Zhi. 2020c; 43(0):E002. Chinese. doi: 10.3760/cma.j.issn.1001-0939.2020.0002.

104. Li H, Zhou Y, Zhang M, Wang H, Zhao Q, Liu J. 2020d. Updated approaches against SARS-CoV-2. Antimicrob Agents Chemother. pii: AAC.00483-20. doi: 10.1128/AAC.00483-20.

105. Liao ZJ, Lei M, Li J, Kaikun LM. 2016. Avian infectious bronchitis virus natural mutant. CN105624122A.

106. Lin L, Li TS. [Interpretation of "Guidelines for the Diagnosis and Treatment of Novel Coronavirus (2019-nCoV) Infection by the National Health Commission (Trial Version 5)"]. Zhonghua Yi Xue Za Zhi. 2020;100(0):E001. Chinese. doi: 10.3760/cma.j.issn.03762491.2020.0001.

107. Liu J, Zheng X, Tong Q, Li W, Wang B, Sutter K, Trilling M, Lu M, Dittmer U, Yang D. Overlapping and discrete aspects of the pathology and pathogenesis of the emerging human pathogenic coronaviruses SARS-CoV, MERS-CoV, and 2019-nCoV. J Med Virol. 2020a; 92(5):491-494. doi: 10.1002/jmv.25709.

108. Liu K, Fang YY, Deng Y, Liu W, Wang MF, Ma JP, Xiao W, Wang YN, Zhong MH, Li $\mathrm{CH}$, Li GC, Liu HG. Clinical characteristics of novel coronavirus cases in tertiary hospitals in Hubei Province. Chin Med J (Engl). 2020b. doi: 10.1097/CM9.0000000000000744.

109. Liu et al. 2020c. Research and Development on Therapeutic Agents and Vaccines for COVID-19 and Related Human Coronavirus Diseases. ACS Cent. Sci. 2020, 6, 3, 315-331

110. Lu MC. 2018. Method for treating a glycoprotein-related disease.US10154985B2.

111. Lu R, Zhao X, Li J, Niu P, Yang B, Wu H, Wang W, Song H, Huang B, Zhu N, Bi Y, Ma X, Zhan F, Wang L, Hu T, Zhou H, Hu Z, Zhou W, Zhao L, Chen J, Meng Y, Wang J, Lin Y, Yuan J, Xie Z, Ma J, Liu WJ, Wang D, Xu W, Holmes EC, Gao GF, Wu G, Chen W, Shi W, Tan W. Genomic characterisation and epidemiology of 2019 novel coronavirus: implications for virus origins and receptor binding. Lancet. 2020a;395(10224):565-574. doi: 10.1016/S0140-6736(20)30251-8.

112. Lu H, Stratton CW, Tang YW. Outbreak of pneumonia of unknown etiology in Wuhan, China: The mystery and the miracle. J Med Virol. 2020b;92(4):401-402. doi: 10.1002/jmv.25678.

113. Lu H. Drug treatment options for the 2019-new coronavirus (2019-nCoV). Biosci Trends. 2020 Mar 16;14(1):69-71. doi: 10.5582/bst.2020.01020. 
114. Malik YS, Sircar S, Bhat S, Sharun K, Dhama K, Dadar M, Tiwari R, Chaicumpa W. Emerging novel coronavirus (2019-nCoV)-current scenario, evolutionary perspective based on genome analysis and recent developments. Vet Q. 2020;40(1):68-76. doi: 10.1080/01652176.2020.1727993.

115. Mao L, Wang M, Chen S, He Q, Chang J, Hong C, Zhou Y, Wang D, Li Y, Jin H, Hu B. Neurological Manifestations of Hospitalized Patients with COVID-19 in Wuhan, China: a retrospective case series study. medRxiv, 2020.2020.02.22.20026500.

116. Marano G, Vaglio S, Pupella S, Facco G, Catalano L, Liumbruno GM, Grazzini G. Convalescent plasma: new evidence for an old therapeutic tool? Blood Transfus. 2016;14(2):152-7. doi: 10.2450/2015.0131-15.

117. Markotter W, Geldenhuys M, Jansen van Vuren P, Kemp A, Mortlock M, Mudakikwa A, Nel L, Nziza J, Paweska J, Weyer J. Paramyxo- and Coronaviruses in Rwandan Bats. Trop Med Infect Dis. 2019;4(3):99. doi: 10.3390/tropicalmed4030099.

118. Marraro GA, Spada C. 2020. Consideration of the respiratory support strategy of severe acute respiratory failure caused by SARS-CoV-2 infection in children. Zhongguo Dang Dai Er Ke Za Zhi. 22(3):183-194.

119. Masters, P.S., Perlman, S., 2013. Coronaviridae, in: Knipe, D.M. and Howley, P.M.(Eds.), Fields virology. Lippincott Williams \& Wilkins, Philadelphia, p 825-858.

120. Matsuyama S, Nao N, Shirato K, Kawase M, Saito S, Takayama I, Nagata N, Sekizuka T, Katoh H, Kato F, Sakata M, Tahara M, Kutsuna S, Ohmagari N, Kuroda M, Suzuki T, Kageyama T, Takeda M. Enhanced isolation of SARS-CoV-2 by TMPRSS2-expressing cells. Proc Natl Acad Sci U S A. 2020:202002589. doi: 10.1073/pnas.2002589117.

121. Millet JK, Whittaker GR. Physiological and molecular triggers for SARS-CoV membrane fusion and entry into host cells. Virology. 2018;517:3-8. doi: 10.1016/j.virol.2017.12.015.

122. Mire CE, Geisbert JB, Agans KN, Thi EP, Lee AC, Fenton KA, Geisbert TW. Passive Immunotherapy: Assessment of Convalescent Serum Against Ebola Virus Makona Infection in Nonhuman Primates. J Infect Dis. 2016;214(suppl 3):S367-S374. doi: 10.1093/infdis/jiw333.

123. Morse JS, Lalonde T, Xu S, Liu WR. Learning from the Past: Possible Urgent Prevention and Treatment Options for Severe Acute Respiratory Infections Caused by 2019-nCoV. Chembiochem. 2020;21(5):730-738. doi: 10.1002/cbic.202000047.

124. Muller MA, Corman VM, Jores J, Meyer B, Younan M, Liljander A, Bosch BJ, Lattwein E, Hilali M, Musa BE, Bornstein S, Drosten C. MERS coronavirus neutralizing antibodies in camels, Eastern Africa, 1983-1997. Emerg Infect Dis 2014;20(12):2093-5. https://doi.org/10.3201/eid2012.141026.

125. Munjal A, Khandia R, Dhama K, Sachan S, Karthik K, Tiwari R, Malik YS, Kumar D, Singh RK, Iqbal HMN, Joshi SK. Advances in Developing Therapies to Combat Zika Virus: Current Knowledge and Future Perspectives. Front Microbiol. 2017;8:1469. doi: 10.3389/fmicb.2017.01469.

126. NIAID 2020. Developing Therapeutics and Vaccines for Coronaviruses. https://www.niaid.nih.gov/diseases-conditions/coronaviruses-therapeutics-vaccines (Accessed on February 15, 2020).

127. Patel A, Jernigan DB; 2019-nCoV CDC Response Team. Initial Public Health Response and Interim Clinical Guidance for the 2019 Novel Coronavirus Outbreak - United States, December 31, 2019-February 4, 2020. MMWR Morb Mortal Wkly Rep. 2020;69(5):140-146. doi: 10.15585/mmwr.mm6905e1. 
128. Peeri NC, Shrestha N, Rahman MS, Zaki R, Tan Z, Bibi S, Baghbanzadeh M, Aghamohammadi N, Zhang W, Haque U. The SARS, MERS and novel coronavirus (COVID-19) epidemics, the newest and biggest global health threats: what lessons have we learned? Int J Epidemiol. 2020:dyaa033. doi: 10.1093/ije/dyaa033.

129. Perlman S, Netland J. Coronaviruses post-SARS: update on replication and pathogenesis. Nat Rev Microbiol. 2009;7(6):439-50. doi: 10.1038/nrmicro2147.

130. Pillaiyar T, Meenakshisundaram S, Manickam M. Recent discovery and development of inhibitors targeting coronaviruses. Drug Discov Today. 2020:S1359-6446(20)30041-6. doi: 10.1016/j.drudis.2020.01.015.

131. Qin C, Zhou L, Hu Z, Zhang S, Yang S, Tao Y, Xie C, Ma K, Shang K, Wang W, Tian DS. Dysregulation of immune response in patients with COVID-19 in Wuhan, China.Clin Infect Dis. 2020:ciaa248. doi: 10.1093/cid/ciaa248.

132. Qiu HB, Li XY, Du B, Kang HYJ, Wang YS, Wang F, Sun B, Tong ZH. [The keypoints in treatment of the critical novel coronavirus pneumonia patient]. Zhonghua Jie $\mathrm{He} \mathrm{He} \mathrm{Hu} \mathrm{Xi}$ Za Zhi. 2020;43(0):E022. Chinese. doi: 10.3760/cma.j.cn112147-20200222-00151.

133. Qureshi A, Tantray VG, Kirmani AR, Ahangar AG. A review on current status of antiviral siRNA. Rev Med Virol. 2018;28(4):e1976. doi: 10.1002/rmv.1976.

134. Radtke KL, Peters H, Neyts J, Jochmans D, Snijder EJ. 2019. Design, synthesis and methods of use of acyclic fleximer nucleoside analogues having anti-coronavirus activity. US10226434B2

135. Rao Z, Sheng F, Yang H, Cheng Y, Yan C, Yan W, He L, Shuang L, Yang X. 2016. Small-molecule inhibitor against MERS-CoV main protease, and preparation method and application thereof. CN105837487A.

136. Ramadan N, Shaib H. Middle East respiratory syndrome coronavirus (MERS-CoV): A review. Germs. 2019;9(1):35-42. doi: 10.18683/germs.2019.1155.

137. Regenmortel, M., et al., Virus taxonomy: Classification and nomenclature of viruses.Seventh report of the International Committee on Taxonomy of Viruses. AcademicPress, 2000. p. 835-849.

138. Rodriguez-Morales AJ, MacGregor K, Kanagarajah S, Patel D, Schlagenhauf P. Going global - Travel and the 2019 novel coronavirus. Travel Med Infect Dis. 2020a;33:101578. doi: 10.1016/j.tmaid.2020.101578.

139. Rodriguez-Morales AJ, Tiwari R, Sah R, Dhama K. COVID-19, an Emerging Coronavirus Infection: Current Scenario and Recent Developments - An Overview. Journal of Pure and Applied Microbiology. 2020b;14: 6150

140. Rohde R. 2019 Novel Coronavirus (2019-nCoV) Update: Uncoating the Virus. 2020. American Society for Microbiology.

141. Roper RL, Rehm KE. SARS vaccines: where are we? Expert Rev Vaccines. 2009;8(7):887-98. doi: 10.1586/erv.09.43.

142. Rosa-Calatrava M, Traversier A, Desuzinges-Mandon E, Dejean E. 2019. Method for preparing a vaccine antigen, resulting vaccine antigen and uses. EP3194423B1.

143. Rothan HA, Byrareddy SN. The epidemiology and pathogenesis of coronavirus disease (COVID-19) outbreak. J Autoimmun. 2020:102433. doi: 10.1016/j.jaut.2020.102433.

144. Schoeman D, Fielding BC. Coronavirus envelope protein: current knowledge. Virol J. 2019;16(1):69. doi: 10.1186/s12985-019-1182-0.

145. Shang W, Yang Y, Rao Y, Rao X. The outbreak of SARS-CoV-2 pneumonia calls for viral vaccines. npj Vaccines. 2020;5:18. doi: 10.1038/s41541-020-0170-0. 
146. Shanmugaraj B, Siriwattananon K, Wangkanont K, Phoolcharoen W. Perspectives on monoclonal antibody therapy as potential therapeutic intervention for Coronavirus disease-19 (COVID-19). Asian Pac J Allergy Immunol. 2020. doi: 10.12932/AP-200220-0773.

147. Sheahan TP, Sims AC, Graham RL, Menachery VD, Gralinski LE, Case JB, Leist SR, Pyrc K, Feng JY, Trantcheva I, Bannister R, Park Y, Babusis D, Clarke MO, Mackman RL, Spahn JE, Palmiotti CA, Siegel D, Ray AS, Cihlar T, Jordan R, Denison MR, Baric RS. Broad-spectrum antiviral GS-5734 inhibits both epidemic and zoonotic coronaviruses. Sci Transl Med. 2017;9(396):eaal3653. doi: 10.1126/scitranslmed.aal3653.

148. Sheahan TP, Sims AC, Leist SR, Schäfer A, Won J, Brown AJ, Montgomery SA, Hogg A, Babusis D, Clarke MO, Spahn JE, Bauer L, Sellers S, Porter D, Feng JY, Cihlar T, Jordan R, Denison MR, Baric RS. Comparative therapeutic efficacy of remdesivir and combination lopinavir, ritonavir, and interferon beta against MERS-CoV. Nat Commun. 2020;11(1):222. doi: 10.1038/s41467-019-13940-6.

149. Shen K, Yang Y, Wang T, Zhao D, Jiang Y, Jin R, Zheng Y, Xu B, Xie Z, Lin L, Shang Y, Lu X, Shu S, Bai Y, Deng J, Lu M, Ye L, Wang X, Wang Y, Gao L; China National Clinical Research Center for Respiratory Diseases; National Center for Children's Health, Beijing, China; Group of Respirology, Chinese Pediatric Society, Chinese Medical Association; Chinese Medical Doctor Association Committee on Respirology Pediatrics; China Medicine Education Association Committee on Pediatrics; Chinese Research Hospital Association Committee on Pediatrics; Chinese Non-government Medical Institutions Association Committee on Pediatrics; China Association of Traditional Chinese Medicine, Committee on Children's Health and Medicine Research; China News of Drug Information Association, Committee on Children's Safety Medication; Global Pediatric Pulmonology Alliance. Diagnosis, treatment, and prevention of 2019 novel coronavirus infection in children: experts' consensus statement. World J Pediatr. 2020. doi: 10.1007/s12519-02000343-7.

150. Shenliang TW. 2016. High-efficiency ranilla luciferase gene expression recombinant HCoV-OC43 (human coronavirus OC43) virus and application thereof. CN105671006A.

151. Shibo J, Xiashuai L, Qian W, Fei Y. 2017. Suppress polypeptide and its application of human coronary virus's infection wide spectrum. CN107022008A.

152. Shin YW, Chang KH, Hong GW, Yeo SG, Jee Y, Kim JH, Oh MD, Cho DH, Kim SH. Selection of Vaccinia Virus-Neutralizing Antibody from a Phage-Display Human-Antibody Library. J Microbiol Biotechnol. 2019;29(4):651-657. doi: 10.4014/jmb.1812.12024.

153. Singh RK, Dhama K, Chakraborty S, Tiwari R, Natesan S, Khandia R, Munjal A, Vora KS, Latheef SK, Karthik K, Singh Malik Y, Singh R, Chaicumpa W, Mourya DT. Nipah virus: epidemiology, pathology, immunobiology and advances in diagnosis, vaccine designing and control strategies - a comprehensive review. Vet Q. 2019;39(1):26-55. doi: 10.1080/01652176.2019.1580827.

154. Singh RK, Dhama K, Khandia R, Munjal A, Karthik K, Tiwari R, Chakraborty S, Malik YS, Bueno-Marí R. Prevention and Control Strategies to Counter Zika Virus, a Special Focus on Intervention Approaches against Vector Mosquitoes-Current Updates. Front Microbiol. 2018;9:87. doi: 10.3389/fmicb.2018.00087.

155. Singh RK, Dhama K, Malik YS, Ramakrishnan MA, Karthik K, Khandia R, Tiwari R, Munjal A, Saminathan M, Sachan S, Desingu PA, Kattoor JJ, Iqbal HM, Joshi SK. Ebola virus - epidemiology, diagnosis, and control: threat to humans, lessons learnt, and 
preparedness plans - an update on its 40 year's journey. Vet Q. 2017;37(1):98-135. doi: 10.1080/01652176.2017.1309474.

156. Song W, Gui M, Wang X, Xiang Y. Cryo-EM structure of the SARS coronavirus spike glycoprotein in complex with its host cell receptor ACE2. PLoS Pathog. 2018;14(8):e1007236. doi: 10.1371/journal.ppat.1007236.

157. Song Z, Xu Y, Bao L, Zhang L, Yu P, Qu Y, Zhu H, Zhao W, Han Y, Qin C. From SARS

to MERS, Thrusting Coronaviruses into the Spotlight. Viruses. 2019;11(1):59. doi: 10.3390/v11010059.

158. Sun ML, Yang JM, Sun YP, Su GH. [Inhibitors of RAS Might Be a Good Choice for the Therapy of COVID-19 Pneumonia]. Zhonghua Jie He He Hu Xi Za Zhi. 2020;43(0):E014. Chinese. doi: 10.3760/cma.j.issn.1001-0939.2020.0014.

159. Sutter G, Fux R, Volz A, Song F, Becker S, Eickmann M. 2016. A novel vaccine against the middle east respiratory syndrome coronavirus (MERS-CoV).EP3045181A1

160. Thi EP, Lee AC, Geisbert JB, Ursic-Bedoya R, Agans KN, Robbins M, Deer DJ, Fenton KA, Kondratowicz AS, MacLachlan I, Geisbert TW, Mire CE. Rescue of non-human primates from advanced Sudan ebolavirus infection with lipid encapsulated siRNA. Nat Microbiol. 2016;1(10):16142. doi: 10.1038/nmicrobiol.2016.142.

161. Thi EP, Mire CE, Lee AC, Geisbert JB, Zhou JZ, Agans KN, Snead NM, Deer DJ, Barnard TR, Fenton KA, MacLachlan I, Geisbert TW. Lipid nanoparticle siRNA treatment of Ebola-virus-Makona-infected nonhuman primates. Nature. 2015;521(7552):362-5. doi: 10.1038/nature14442.

162. Thomsen AR, Christensen JP, Grujic M. 2019. Priming of an immune response. JP2019146588A.

163. Ton AT, Gentile F, Hsing M, Ban F, Cherkasov A. Rapid Identification of Potential Inhibitors of SARS-CoV-2 Main Protease by Deep Docking of 1.3 Billion Compounds. Mol Inform. 2020. doi: 10.1002/minf.202000028.

164. Toots M, Yoon JJ, Cox RM, Hart M, Sticher ZM, Makhsous N, Plesker R, Barrena AH, Reddy PG, Mitchell DG, Shean RC, Bluemling GR, Kolykhalov AA, Greninger AL, Natchus MG, Painter GR, Plemper RK. Characterization of orally efficacious influenza drug with high resistance barrier in ferrets and human airway epithelia. Sci Transl Med. 2019;11(515):eaax5866. doi: 10.1126/scitranslmed.aax5866.

165. Tortorici MA, Veesler D. Structural insights into coronavirus entry. Adv Virus Res. 2019;105:93-116. doi: 10.1016/bs.aivir.2019.08.002.

166. Traggiai E, Becker S, Subbarao K, Kolesnikova L, Uematsu Y, Gismondo MR, Murphy BR, Rappuoli R, Lanzavecchia A. An efficient method to make human monoclonal antibodies from memory B cells: potent neutralization of SARS coronavirus. Nat Med. 2004;10(8):871-5. doi: 10.1038/nm1080.

167. Tsai CH, Lee PY, Stollar V, Li ML. Antiviral therapy targeting viral polymerase. Curr Pharm Des. 2006;12(11):1339-55. doi: 10.2174/138161206776361156.

168. van Boheemen S, de Graaf M, Lauber C, Bestebroer TM, Raj VS, Zaki AM, Osterhaus AD, Haagmans BL, Gorbalenya AE, Snijder EJ, Fouchier RA. Genomic characterization of a newly discovered coronavirus associated with acute respiratory distress syndrome in humans. mBio. 2012;3(6):e00473-12. doi: 10.1128/mBio.00473-12.

169. Van Der Hoek C. 2007. Coronavirus, nucleic acid, protein, and methods for the generation of vaccine, medicaments and diagnostics. JP2007502612A. 
170. Vijayanand P, Wilkins E, Woodhead M. Severe acute respiratory syndrome (SARS): a review. Clin Med (Lond). 2004;4(2):152-60. doi: 10.7861/clinmedicine.4-2-152.

171. Walls AC, Park YJ, Tortorici MA, Wall A, McGuire AT, Veesler D. Structure, Function, and Antigenicity of the SARS-CoV-2 Spike Glycoprotein. Cell. 2020:S0092-8674(20)302622. doi: 10.1016/j.cell.2020.02.058.

172. Walls AC, Tortorici MA, Bosch BJ, Frenz B, Rottier PJM, DiMaio F, Rey FA, Veesler D. Cryo-electron microscopy structure of a coronavirus spike glycoprotein trimer. Nature. 2016;531(7592):114-117. doi: 10.1038/nature16988.

173. Wang L, Shi W, Chappell JD, Joyce MG, Zhang Y, Kanekiyo M, Becker MM, van Doremalen N, Fischer R, Wang N, Corbett KS, Choe M, Mason RD, Van Galen JG, Zhou T, Saunders KO, Tatti KM, Haynes LM, Kwong PD, Modjarrad K, Kong WP, McLellan JS, Denison MR, Munster VJ, Mascola JR, Graham BS. Importance of Neutralizing Monoclonal Antibodies Targeting Multiple Antigenic Sites on the Middle East Respiratory Syndrome Coronavirus Spike Glycoprotein To Avoid Neutralization Escape. J Virol. 2018;92(10):e02002-17. doi: 10.1128/JVI.02002-17.

174. Wang W, Xu Y, Gao R, Lu R, Han K, Wu G, Tan W. Detection of SARS-CoV-2 in Different Types of Clinical Specimens. JAMA. 2020a:e203786. doi: 10.1001/jama.2020.3786.

175. Wang M, Wu Q, Xu W, Qiao B, Wang J, Zheng H, Jiang S, Mei J, Wu Z, Deng Y, Zhou F, Wu W, Zhang Y, Lv Z, Huang J, Guo X, Feng L, Xia Z, Li Di, Xu Z, Liu T, Zhang P, Tong Y, Li Y.. Clinical diagnosis of 8274 samples with 2019-novel coronavirus in Wuhan. medRxiv. 2020b.2020.02.12.20022327. doi: 10.1101/2020.02.12.20022327.

176. Wang M, Cao R, Zhang L, Yang X, Liu J, Xu M, Shi Z, Hu Z, Zhong W, Xiao G. Remdesivir and chloroquine effectively inhibit the recently emerged novel coronavirus (2019-nCoV) in vitro. Cell Res. 2020c;30(3):269-271. doi: 10.1038/s41422-020-0282-0.

177. Wang Z, Chen X, Lu Y, Chen F, Zhang W. Clinical characteristics and therapeutic procedure for four cases with 2019 novel coronavirus pneumonia receiving combined Chinese and Western medicine treatment. Biosci Trends. 2020d;14(1):64-68. doi: 10.5582/bst.2020.01030.

178. Wang Q, Wong G, Lu G, Yan J, Gao GF. MERS-CoV spike protein: Targets for vaccines and therapeutics. Antiviral Res. 2016;133:165-77. doi: 10.1016/j.antiviral.2016.07.015.

179. Wei L, Chengqiu L, Yanhua S, Yongfei P, Shuang S, Dongdong W. 2016. Primers, probe, kit and method for detecting bovine coronavirus. CN105671209A.

180. Weiner D, Muthumani K, Sardesai NY. 2020. MERS-CoV vaccine.US10548971B2.

181. Who is getting sick, and how sick? A breakdown of coronavirus risk by demographic factors. Accessed March 14, 2020. https://www.statnews.com/2020/03/03/who-is-gettingsick-and-how-sick-a-breakdown-of-coronavirus-risk-by-demographic-factors/.

182. WHO. 2020a. Situation Report - 55. https://www.who.int/docs/defaultsource/coronaviruse/situation-reports/20200315-sitrep-55-covid 19.pdf?sfvrsn=33daa5cb_6.

183. WHO. 2020b. Cumulative number of reported probable cases of SARS. https://www.who.int/csr/sars/country/2003_07_11/en/. Accessed January 17, 2020.

184. WHO. 2020c. Middle East respiratory syndrome coronavirus (MERS-CoV). HYPERLINK "https://www.who.int/emergencies/mers-cov/en/" It "_blank" https://www.who.int/emergencies/mers-cov/en/ . Accessed January 17, 2020.

185. WHO. 2020d. Clinical management of severe acute respiratory infection when novel coronavirus (nCoV) infection is suspected. Jan 28, 2020. accessed Mar 15, 
2020.https://www.who.int/publications-detail/clinical-management-of-severeacuterespiratory-infection-when-novel-coronavirus-(ncov)-infection-issuspected

186. WHO. 2020e. DRAFT landscape of COVID-19 candidate vaccines - 4 March 2020. https://www.who.int/blueprint/priority-diseases/key-action/novel-coronavirus-landscapencov.pdf?ua=1.

187. Wilson ME, Chen LH. Travellers give wings to novel coronavirus (2019-nCoV). J Travel Med. 2020;27(2):taaa015. doi: 10.1093/jtm/taaa015.

188. Wu A, Peng Y, Huang B, Ding X, Wang X, Niu P, Meng J, Zhu Z, Zhang Z, Wang J, Sheng J. Genome composition and divergence of the novel coronavirus (SARS-CoV-2) originating in China. Cell Host \& Microbe. 2020a.

189. Wu F, Zhao S, Yu B, Chen YM, Wang W, Song ZG, Hu Y, Tao ZW, Tian JH, Pei YY, Yuan ML, Zhang YL, Dai FH, Liu Y, Wang QM, Zheng JJ, Xu L, Holmes EC, Zhang YZ. A new coronavirus associated with human respiratory disease in China. Nature. 2020b;579(7798):265-269. doi: 10.1038/s41586-020-2008-3.

190. Xiao Y, Torok ME. Taking the right measures to control COVID-19. Lancet Infect Dis. 2020:S1473-3099(20)30152-3. doi: 10.1016/S1473-3099(20)30152-3.

191. Xu YH, Dong JH, An WM, Lv XY, Yin XP, Zhang JZ, Dong L, Ma X, Zhang HJ, Gao BL. Clinical and computed tomographic imaging features of novel coronavirus pneumonia caused by SARS-CoV-2. J Infect. 2020:S0163-4453(20)30100-6. doi: 10.1016/j.jinf.2020.02.017.

192. Xue X, Yu H, Yang H, Xue F, Wu Z, Shen W, Li J, Zhou Z, Ding Y, Zhao Q, Zhang XC, Liao M, Bartlam M, Rao Z. Structures of two coronavirus main proteases: implications for substrate binding and antiviral drug design. J Virol. 2008;82(5):2515-27. doi: 10.1128/JVI.02114-07.

193. Yang Y, Peng F, Wang R, Guan K, Jiang T, Xu G, Sun J, Chang C. The deadly coronaviruses: The 2003 SARS pandemic and the 2020 novel coronavirus epidemic in China. J Autoimmun. 2020a:102434. doi: 10.1016/j.jaut.2020.102434.

194. Yang T, Wang YC, Shen CF, Cheng CM. Point-of-Care RNA-Based Diagnostic Device for COVID-19. Diagnostics (Basel). 2020b;10(3):E165. doi: 10.3390/diagnostics10030165.

195. Yao TT, Qian JD, Zhu WY, Wang Y, Wang GQ. A systematic review of lopinavir therapy for SARS coronavirus and MERS coronavirus-A possible reference for coronavirus disease-19 treatment option. J Med Virol. 2020. doi: 10.1002/jmv.25729.

196. Youngren-Ortiz SR, Gandhi NS, España-Serrano L, Chougule MB. Aerosol Delivery of siRNA to the Lungs. Part 1: Rationale for Gene Delivery Systems. Kona. 2016;33:63-85. doi: 10.14356/kona.2016014.

197. Yu L, Wu S, Hao X, Li X, Liu X, Ye S, Han H, Dong X, Li X, Li J, Liu J, Liu N, Zhang W, Pelechano V, Chen WH, Yin X. Rapid colorimetric detection of COVID-19 coronavirus using a reverse tran-scriptional loop-mediated isothermal amplification (RT-LAMP) diagnostic plat-form: Ilaco. medRxiv. 2020a. doi: 10.1101/2020.02.20.20025874.

198. Yu F, Du L, Ojcius DM, Pan C, Jiang S. Measures for diagnosing and treating infections by a novel coronavirus responsible for a pneumonia outbreak originating in Wuhan, China. Microbes Infect. 2020b:S1286-4579(20)30025-3. doi: 10.1016/j.micinf.2020.01.003.

199. Zhang T, Wu Q, Zhang Z. Probable Pangolin Origin of SARS-CoV-2 Associated with the COVID-19 Outbreak. Curr Biol. 2020a:S0960-9822(20)30360-2. doi: 10.1016/j.cub.2020.03.022. 
200. Zhang N, Wang L, Deng X, Liang R, Su M, He C, Hu L, Su Y, Ren J, Yu F, Du L, Jiang S. Recent advances in the detection of respiratory virus infection in humans. J Med Virol. 2020b;92(4):408-417. doi: 10.1002/jmv.25674.

201. Zhang J, Zhou L, Yang Y, Peng W, Wang W, Chen X. Therapeutic and triage strategies for 2019 novel coronavirus disease in fever clinics. Lancet Respir Med. 2020c;8(3):e11-e12. doi: 10.1016/S2213-2600(20)30071-0.

202. Zhao J, Perera RA, Kayali G, Meyerholz D, Perlman S, Peiris M. Passive immunotherapy with dromedary immune serum in an experimental animal model for Middle East respiratory syndrome coronavirus infection. J Virol. 2015;89(11):6117-20. doi: 10.1128/JVI.00446-15.

203. Zhou P, Yang XL, Wang XG, Hu B, Zhang L, Zhang W, Si HR, Zhu Y, Li B, Huang CL, Chen HD, Chen J, Luo Y, Guo H, Jiang RD, Liu MQ, Chen Y, Shen XR, Wang X, Zheng XS, Zhao K, Chen QJ, Deng F, Liu LL, Yan B, Zhan FX, Wang YY, Xiao GF, Shi ZL. Discovery of a novel coronavirus associated with the recent pneumonia outbreak in humans and its potential bat origin. 2020 .2001.2022.914952, doi:10.1101/2020.01.22.914952.

204. Zhu N, Zhang D, Wang W, Li X, Yang B, Song J, Zhao X, Huang B, Shi W, Lu R, Niu P, Zhan F, Ma X, Wang D, Xu W, Wu G, Gao GF, Tan W; China Novel Coronavirus Investigating and Research Team. A Novel Coronavirus from Patients with Pneumonia in China, 2019. N Engl J Med. 2020;382(8):727-733. doi: 10.1056/NEJMoa2001017.

205. Zhu Z, Zhang Z, Chen W, Cai Z, Ge X, Zhu H, Jiang T, Tan W, Peng Y. Predicting the receptor-binding domain usage of the coronavirus based on kmer frequency on spike protein. Infect Genet Evol. 2018;61:183-184. doi: 10.1016/j.meegid.2018.03.028.

206. Zumla A, Chan JF, Azhar EI, Hui DS, Yuen KY. Coronaviruses - drug discovery and therapeutic options. Nat Rev Drug Discov. 2016;15(5):327-47. doi: 10.1038/nrd.2015.37. 


\section{Legends of Figures and Tables}

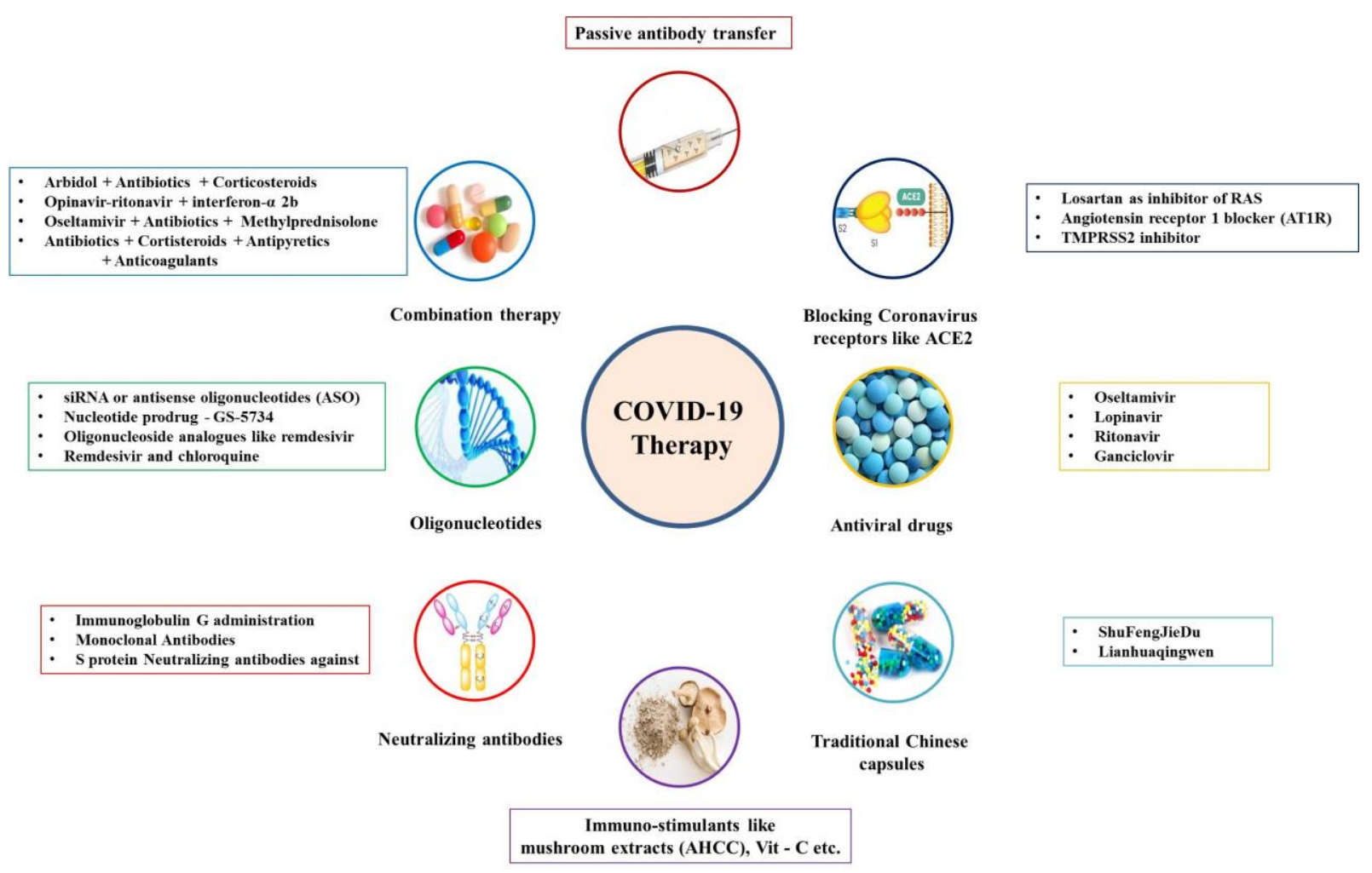

Figure 1. An overview on COVID-19 therapeutics and drugs. 


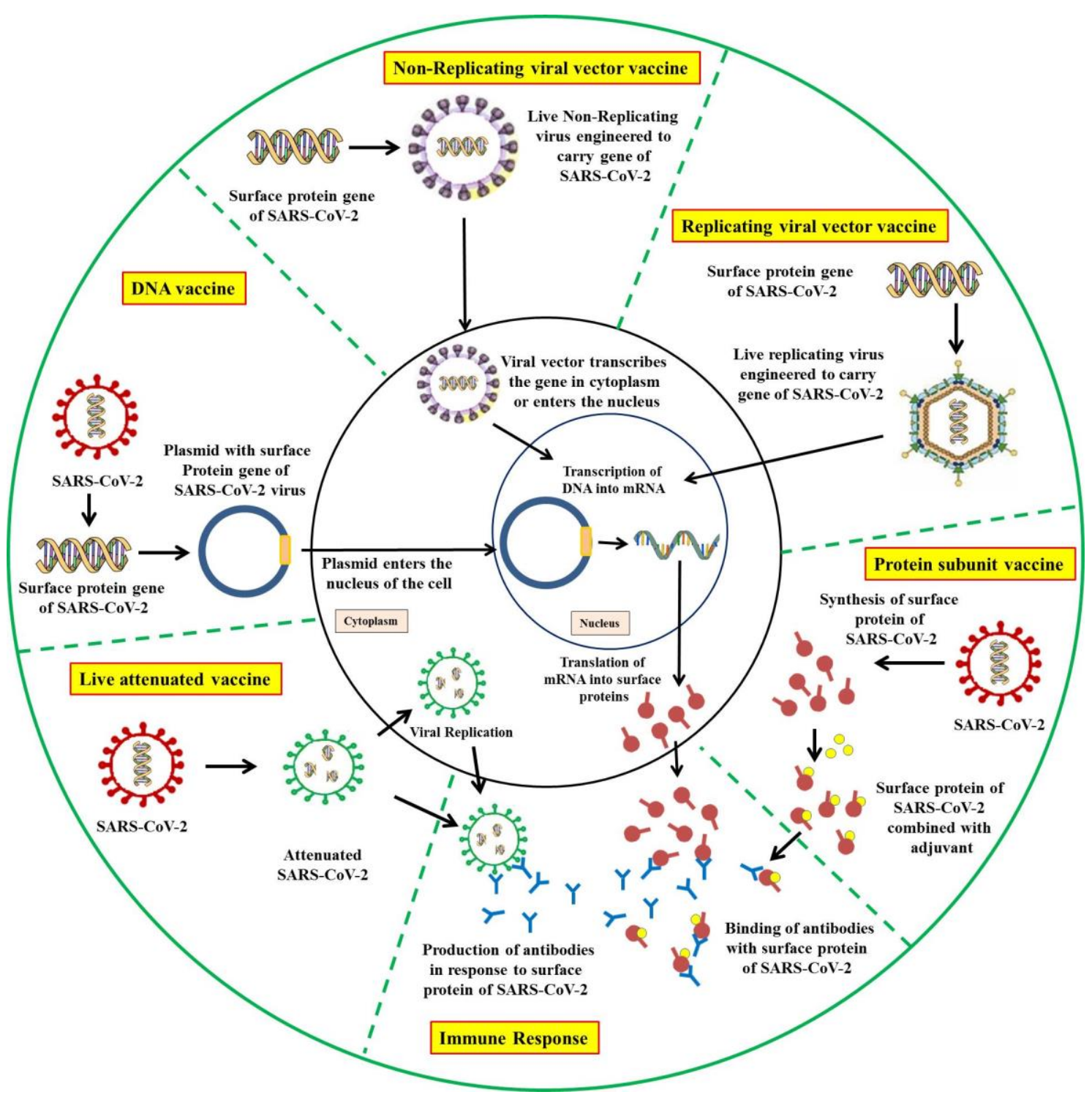

Figure 2. An overview on designing and developing COVID-19 vaccines. 
Table 1. Classification of Coronavirus.

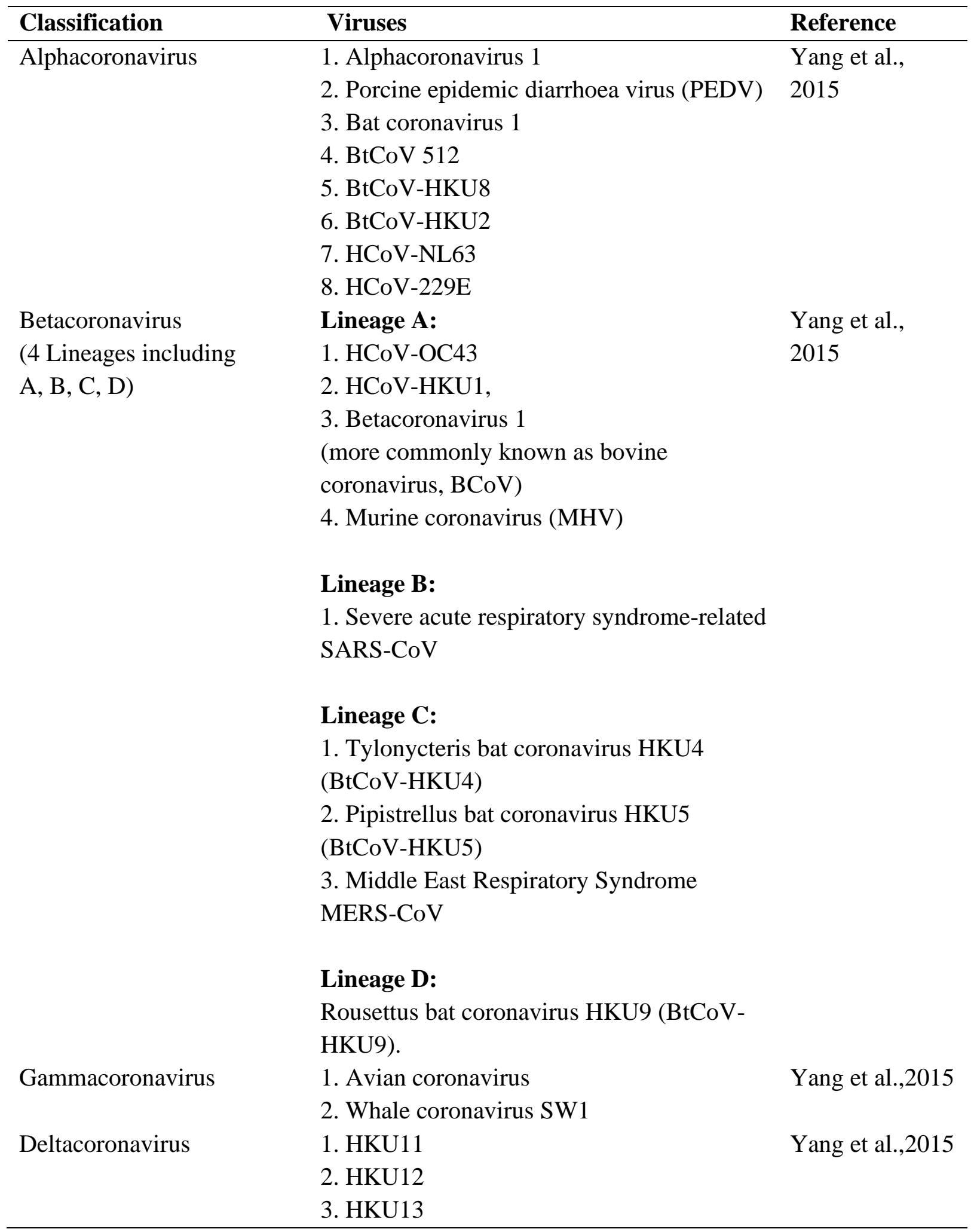


Table 2. Patents on methodologies of different aspects of coronaviruses.

\begin{tabular}{|c|c|c|c|c|c|}
\hline Patent No. & Date & Basis & Research/patent title & Findings & Reference \\
\hline $2016-07-20$ & EP3045181A1 & Vaccine & $\begin{array}{l}\text { A novel vaccine against the middle } \\
\text { east respiratory syndrome coronavirus } \\
\text { (MERS-CoV) }\end{array}$ & $\begin{array}{l}\text { The invention relates an immunogenic composition comprising the } \\
\text { MERS-CoVN nucleocapsid protein and/or an immunogenic fragment } \\
\text { thereof, or a nucleic acid molecule encoding the MERS-CoV N } \\
\text { nucleocapsid protein and/or the immunogenic fragment thereof. } \\
\text { Furthermore, the present invention relates to a vector comprising a } \\
\text { nucleic acid molecule encoding the MERS-CoV N nucleocapsid } \\
\text { protein and/or an immunogenic fragment thereof, for use as a vaccine } \\
\text { as well as a method of inducing a protective immune response against } \\
\text { MERS-CoV. }\end{array}$ & Sutter et al. 2016 \\
\hline $2007-02-15$ & JP2007502612A & $\begin{array}{l}\text { Diagnosis, } \\
\text { Vaccine }\end{array}$ & $\begin{array}{l}\text { Coronavirus, nucleic acid, protein, and } \\
\text { methods for the generation of vaccine, } \\
\text { medicaments and diagnostics }\end{array}$ & $\begin{array}{l}\text { A new coronavirus (human coronavirus NL63 (HCoV-NL63) is } \\
\text { disclosed herein with a tropism that includes humans. Means and } \\
\text { methods are provided for diagnosing subjects (previously) infected } \\
\text { with the virus. Also provided are among other vaccines, medicaments, } \\
\text { nucleic acids and specific binding members }\end{array}$ & Van Der Hoek, 2007 \\
\hline 2012-07-05 & ES2384445T3 & Vaccine & $\begin{array}{l}\text { Spike protein of canine respiratory } \\
\text { coronavirus (crcv), polymerase and } \\
\text { hemaglutinin / esterase. }\end{array}$ & $\begin{array}{l}\text { A vaccine composition for vaccinating dogs, the composition } \\
\text { comprising: a canine respiratory coronavirus (CRCV) comprising a } \\
\text { Spike (S) protein having the amino acid sequence listed in Figure } 4 \text {, or } \\
\text { a coronaviral S protein having at least } 97 \% \text { amino acid identity with } \\
\text { the amino acid sequence of Figure } 4 \text {, or an immunogenic fragment of } \\
\text { Figure } 4 \text { of at least } 200 \text { amino acids in length, or a nucleic acid } \\
\text { encoding said coronaviral } S \text { protein or said immunogenic fragment }\end{array}$ & Brownlie et al. 2012 \\
\hline $2017-10-12$ & WO2017176596A1 & Vaccine & $\begin{array}{l}\text { Multivalent vaccines for rabies virus } \\
\text { and coronaviruses }\end{array}$ & $\begin{array}{l}\text { The present disclosure provides methods and compositions for } \\
\text { inducing an immune response that confers dual protection against } \\
\text { infections by either or both of a rabies virus and a coronavirus, and/or } \\
\text { which can be used therapeutically for an existing infection with rabies } \\
\text { virus and/or a coronavirus to treat at least one symptom thereof and/or } \\
\text { to neutralize or clear the infecting agents. In particular, the present } \\
\text { disclosure provides a recombinant rabies virus vector comprising a } \\
\text { nucleotide sequence encoding at least one coronavirus immunogenic } \\
\text { glycoprotein fragment, as well as pharmaceutical compositions } \\
\text { comprising the vaccine vectors. }\end{array}$ & Johnson et al. 2017 \\
\hline $2017-12-28$ & WO2017222935A1 & $\begin{array}{l}\text { Treatment and } \\
\text { control }\end{array}$ & $\begin{array}{l}\text { Small molecule therapeutic inhibitors } \\
\text { against picornaviruses, caliciviruses, }\end{array}$ & $\begin{array}{l}\text { Antiviral protease inhibitors are disclosed, along with related antiviral } \\
\text { dipeptidyl compounds, macrocyclic derivatives thereof, and methods } \\
\text { of using the same to treat or prevent viral infection and disease from }\end{array}$ & Chang et al. 2017 \\
\hline
\end{tabular}




\begin{tabular}{|c|c|c|c|c|c|}
\hline & & & and coronaviruses & coronaviruses, caliciviruses, and picornaviruses. & \\
\hline $2018-05-22$ & S9975885B2 & $\begin{array}{l}\text { Treatment and } \\
\text { control }\end{array}$ & $\begin{array}{l}\text { Broad-spectrum non-covalent } \\
\text { coronavirus protease inhibitors }\end{array}$ & $\begin{array}{l}\text { This invention pertains to materials and methods for the treatment of } \\
\text { patients with coronavirus infection and the control of zoonotic disease } \\
\text { outbreaks using broad-spectrum non-covalent coronavirus protease } \\
\text { inhibitors. }\end{array}$ & Emma et al. 2018 \\
\hline 2017-08-03 & WO2017129975A1 & Vaccine & Attenuated infectious bronchitis virus & $\begin{array}{l}\text { The present invention provides a live, attenuated coronavirus } \\
\text { comprising a mutation in non-structural protein nsp- } 3 \text { and/or deletion } \\
\text { of accessory proteins } 3 \mathrm{a} \text { and } 3 \mathrm{~b} \text {. The coronavirus may be used as a } \\
\text { vaccine for treating and/or preventing a disease, such as infectious } \\
\text { bronchitis, in a subject. }\end{array}$ & Bickerton et al. 2017 \\
\hline 2019-12-05 & JP2019206573A & $\begin{array}{l}\text { Immunity } \\
\text { boosters }\end{array}$ & $\begin{array}{l}\text { Immunomodulation methods and } \\
\text { compositions }\end{array}$ & $\begin{array}{l}\text { Methods and compositions for immunomodulation are provided. Cells } \\
\text { containing exogenous antigens and uses thereof are provided. The } \\
\text { present invention includes, for example, a method of inducing immune } \\
\text { tolerance, comprising enucleated hematopoietic cells that express an } \\
\text { exogenous antigen to a human subject suffering from or at risk of } \\
\text { developing an autoimmune disease, disorder or condition } \\
\text { Administering a pharmaceutical composition, wherein the } \\
\text { pharmaceutical composition is administered in an amount effective to } \\
\text { induce immune tolerance in the subject against the antigen that } \\
\text { mediates the autoimmune disease, disorder or condition }\end{array}$ & Jordi et al. 2019 \\
\hline $2020-01-02$ & US20200002370A1 & $\begin{array}{l}\text { Treatment, } \\
\text { adjuvants }\end{array}$ & Novel Compounds & $\begin{array}{l}\text { The invention also relates to the use of said compounds, combinations, } \\
\text { compositions and medicaments, in the treatment of diseases in which } \\
\text { modulation of STING (Stimulator of Interferon Genes) is beneficial, } \\
\text { for example inflammation, allergic and autoimmune diseases, } \\
\text { infectious diseases, cancer, pre-cancerous syndromes and as vaccine } \\
\text { adjuvants. }\end{array}$ & Adams and Lian 2020 \\
\hline 2019-11-14 & US20190343862A1 & $\begin{array}{l}\text { Immunomodulat } \\
\text { ors }\end{array}$ & $\begin{array}{l}\text { Delivery of RNA to trigger multiple } \\
\text { immune pathways }\end{array}$ & $\begin{array}{l}\text { RNA encoding an immunogen is co-delivered to non-immune cells at } \\
\text { the site of delivery and also to immune cells which infiltrate the site of } \\
\text { delivery. The responses of these two cell types to the same delivered } \\
\text { RNA lead to two different effects, which interact to produce a strong } \\
\text { immune response against the immunogen. The non-immune cells } \\
\text { translate the RNA and express the immunogen. Infiltrating immune } \\
\text { cells respond to the RNA by expressing type I interferons and pro- } \\
\text { inflammatory cytokines which produce a local adjuvant effect which }\end{array}$ & Geall et al. 2019 \\
\hline
\end{tabular}




\begin{tabular}{|c|c|c|c|c|c|}
\hline & & & & $\begin{array}{l}\text { acts on the immunogen-expressing non-immune cells to upregulate } \\
\text { major histocompatibility complex expression, thereby increasing } \\
\text { presentation of the translated protein to } T \text { cells. The effects on the } \\
\text { immune and non-immune cells can be achieved by a single delivery of } \\
\text { a single RNA e.g. by a single injection. }\end{array}$ & \\
\hline 2018-12-18 & US10154985B2 & Treatment & $\begin{array}{l}\text { Method for treating a glycoprotein- } \\
\text { related disease }\end{array}$ & $\begin{array}{l}\text { A method for treating a glycoprotein-related disease is disclosed, } \\
\text { which comprises: administering a first effective amount of phenol red } \\
\text { and a second effective amount of an organic arsenic compound to a } \\
\text { subject in need thereof. }\end{array}$ & $\mathrm{Lu}, 2018$ \\
\hline 2016-11-24 & US20160339097A1 & $\begin{array}{l}\text { Recombinant } \\
\text { vaccine proteins }\end{array}$ & Coronavirus proteins and antigens & $\begin{array}{l}\text { Disclosed herein are embodiments of a method for collecting, } \\
\text { extracting or eluting proteins and antigens from cells infected with } \\
\text { coronavirus. The coronavirus may be a porcine coronavirus, such as } \\
\text { porcine epidemic diarrhea virus (PEDV) or porcine delta coronavirus } \\
\text { (PDCoV). Also disclosed are embodiments of a composition } \\
\text { comprising the coronavirus proteins and antigens, and embodiments of } \\
\text { a method of using such a composition. Applications for the } \\
\text { composition include, but are not limited to, use in the preparation of } \\
\text { antibodies against the proteins and antigens, use as reference markers } \\
\text { for coronavirus proteins, and/or use in an immunogenic composition, } \\
\text { such as in a vaccine composition }\end{array}$ & Kim, 2016 \\
\hline 2017-01-19 & WO2017010835A1 & Drug/treatment & $\begin{array}{l}\text { Use of radotinib for prevention or } \\
\text { treatment of viral respiratory disease }\end{array}$ & $\begin{array}{l}\text { The present invention relates to a novel use of a compound of } \\
\text { Chemical Formula } 1 \text { (radotinib) in the prevention or treatment of viral } \\
\text { respiratory disease. According to the present invention, a compound of } \\
\text { Chemical Formula } 1 \text { or a pharmaceutically acceptable salt thereof can } \\
\text { be used for the prevention, alleviation or treatment of coronavirus } \\
\text { infection. Specifically, the present invention can be used as a useful } \\
\text { antiviral agent for the prevention or treatment of disease caused by } \\
\text { infection of Middle East respiratory syndrome-coronavirus (MERS- } \\
\text { CoV). }\end{array}$ & Kim et al. 2017 \\
\hline 2016-06-15 & CN105671209A & Diagnosis & $\begin{array}{l}\text { Primers, probe, kit and method for } \\
\text { detecting bovine coronavirus }\end{array}$ & $\begin{array}{l}\text { The invention discloses primers, a probe, a kit and a method for } \\
\text { detecting bovine coronavirus. The method comprises the following } \\
\text { steps: by using cDNA (complementary deoxyribonucleic acid) } \\
\text { obtained by carrying out RNA (ribonucleic acid) reverse transcription } \\
\text { on the detected sample as a template, carrying out fluorescent } \\
\text { quantitative PCR (polymerase chain reaction) amplification, and } \\
\text { comparing the amplification curve CT value. The quantitative PCR } \\
\text { primers are designed at the bovine coronavirus conserved gene (N }\end{array}$ & Wei et al. 2016 \\
\hline
\end{tabular}




\begin{tabular}{|c|c|c|c|c|c|}
\hline & & & & $\begin{array}{l}\text { gene), and a probe process is adopted to establish a fluorescent } \\
\text { quantitative PCR method. The primers, probe, kit and method are } \\
\text { simple and practical to operate, have the advantages of high } \\
\text { specificity, high sensitivity and favorable repetitiveness, and are } \\
\text { suitable for the demands for quick and accurate detection of } \\
\text { modernized cultivation farms. }\end{array}$ & \\
\hline $2016-06-15$ & CN105671006A & $\begin{array}{l}\text { Diagnosis and } \\
\text { treatment }\end{array}$ & $\begin{array}{l}\text { High-efficiency ranilla luciferase gene } \\
\text { expression recombinant } \mathrm{HCoV-OC43} \\
\text { (human coronavirus OC43) virus and } \\
\text { application thereof }\end{array}$ & $\begin{array}{l}\text { The invention discloses a high-efficiency ranilla luciferase gene } \\
\text { expression recombinant human coronavirus OC43 virus and } \\
\text { application thereof to screening of antiviral medicines. By an overlap } \\
\text { PCR (polymerase chain reaction) method, a ranilla luciferase gene is } \\
\text { replaced or inserted into accessory genes (ns2 and ns12.9) to be cloned } \\
\text { into human coronavirus OC43 full-length infectious clone pBAC- } \\
\text { OC43FL, and four ranilla luciferase gene expression recombinant } \\
\text { viruses, including rOC43-ns2DelRluc, rOC43-ns2FusionRluc, rOC43- } \\
\text { ns12.9StopRluc and rOC43-ns12.9FusionRluc, are obtained } \\
\text { respectively. The virus rOC43-ns2DelRluc is efficient in ranilla } \\
\text { luciferase gene expression and similar to a parent virus HCoV-OC43- } \\
\text { WT in virus growth curve, the inserted reporter gene is stable in a } \\
\text { serial passage process, and the virus rOC43-ns2DelRluc can be } \\
\text { successfully applied to antiviral medicine screening experiments and } \\
\text { has an extensive application prospect in high-throughput screening of } \\
\text { anti-coronavirus medicines and host antiviral genes. }\end{array}$ & Shenliang, 2016 \\
\hline $2016-08-10$ & CN105837487A & $\begin{array}{l}\text { Prevention } \\
\text { /treatment }\end{array}$ & $\begin{array}{l}\text { Small-molecule inhibitor against } \\
\text { MERS-CoV main protease, and } \\
\text { preparation method and application } \\
\text { thereof }\end{array}$ & $\begin{array}{l}\text { The invention provides a small-molecule inhibitor against MERS-CoV } \\
\text { main protease. The small-molecule inhibitor is designed on the basis } \\
\text { of the crystal structure of main protease of the novel coronavirus } \\
\text { MERS-CoV. The invention also provides a synthetic method for the } \\
\text { small-molecule inhibitor and application of the small-molecule } \\
\text { inhibitor in preparation of drugs used for preventing and treating } \\
\text { MERS-CoV infections. The small-molecule inhibitor against MERS- } \\
\text { CoV main protease can substantially inhibit the activity of main } \\
\text { protease of the MERS coronavirus, has good inhibitory activity to } \\
\text { main protease of coronaviruses like SARS and MHV, and presents } \\
\text { good application prospects in preparation of drugs used for preventing } \\
\text { or treating coronavirus infections. }\end{array}$ & Rao et al. 2016 \\
\hline 2016-09-01 & WO2016138160A1 & $\begin{array}{l}\text { Recombinant } \\
\text { peptides/antibodi } \\
\text { es treatment }\end{array}$ & $\begin{array}{l}\text { Middle east respiratory syndrome } \\
\text { coronavirus immunogens, antibodies, } \\
\text { and their use }\end{array}$ & $\begin{array}{l}\text { Methods of inducing an immune response in a subject to the Middle } \\
\text { East respiratory syndrome coronavirus (MERS-CoV) are provided. In } \\
\text { several embodiments, the immune response is a protective immune } \\
\text { response that inhibits or prevents MERS-CoV infection in the subject. }\end{array}$ & Graham et al. 2016 \\
\hline
\end{tabular}




\begin{tabular}{|c|c|c|c|c|c|}
\hline & & & & $\begin{array}{l}\text { Recombinant MERS-CoV polypeptides and nucleic acid molecules } \\
\text { encoding same are also provided. Additionally, neutralizing antibodies } \\
\text { that specifically bind to MERS-CoV S protein and antigen binding } \\
\text { fragments thereof are disclosed. The antibodies and antigen binding } \\
\text { fragments are useful, for example, in methods of detecting MERS- } \\
\text { CoV S protein in a sample or in a subject, as well as methods of } \\
\text { preventing and treating a MERS-CoV infection in a subject. }\end{array}$ & \\
\hline 2016-06-01 & CN105624122A & $\begin{array}{l}\text { Mutant virus as } \\
\text { vaccine }\end{array}$ & $\begin{array}{l}\text { Avian infectious bronchitis virus } \\
\text { natural mutant }\end{array}$ & $\begin{array}{l}\text { The invention relates to the field of virology and aims to provide an } \\
\text { avian infectious bronchitis virus natural mutant, kept in China General } \\
\text { Microbiological Culture Collection Center, named infectious } \\
\text { bronchitis virus and collected under CGMCC No. 11491. A genome of } \\
\text { this mutant is } 27,541 \text { lbp in length, a complete genome sequence of } \\
\text { the mutant is as shown in SEQ ID NO: } 1 \text {, with structural } \\
\text { characteristics of a typical IBV genome coding structure. This mutant } \\
\text { having special genes inserted in and provided by the invention can } \\
\text { break the immunity protection of vaccines to breed in an organism, } \\
\text { this mutant can proliferate in susceptible chickens without causing } \\
\text { significant pathogenicity to sensitive chickens, and thus this mutant } \\
\text { can serve as base material for the further study on mutation } \\
\text { mechanism of an attenuated vaccine or IBV virus strain. }\end{array}$ & Liao et al. 2016 \\
\hline $2017-08-08$ & CN107022008A & $\begin{array}{l}\text { Prevention and } \\
\text { treatment }\end{array}$ & $\begin{array}{l}\text { Suppress polypeptide and its } \\
\text { application of human coronary virus's } \\
\text { infection wide spectrum }\end{array}$ & $\begin{array}{l}\text { The invention belongs to biomedicine field, it is related to the } \\
\text { polypeptide for suppressing human coronary virus's infection, and in } \\
\text { particular to polypeptide and its application of human coronary virus's } \\
\text { infection can be suppressed wide spectrum. The S2 regions based on } \\
\text { coronavirus S protein of the invention are more conservative and } \\
\text { feature of with similar syncretizing mechanism provide can be to } \\
\text { polypeptide of the infection with wide spectrum inhibitory action of } \\
\text { two or more human coronary virus. The present invention is the results } \\
\text { showed obtain " general character " of human coronary virus, the } \\
\text { identical syncretizing mechanism in i.e. similar HR regions and its } \\
\text { mediation, and provide the serial polypeptides of HCoV-EK as point } \\
\text { of penetration, the polypeptide not only has preferable inhibition to } \\
\text { some currently a popular human corona viruses, and equally has good } \\
\text { inhibitory activity to the class SARS virus (RsSHC014-CoV or } \\
\text { RsW1V1-CoV) for being possible to infect the mankind.The present } \\
\text { invention can provide the drug candidate of prevention and treatment } \\
\text { for the novel human coronavirus for being still possible to outburst in } \\
\text { popular human corona virus and future at present. }\end{array}$ & Shibo et al., 2017 \\
\hline
\end{tabular}




\begin{tabular}{|c|c|c|c|c|c|}
\hline 2018-02-13 & US9889194B2 & $\begin{array}{l}\text { Immunogenic } \\
\text { proteins }\end{array}$ & $\begin{array}{l}\text { Immunogenic composition for MERS } \\
\text { coronavirus infection }\end{array}$ & $\begin{array}{l}\text { Described herein are immunogenic compositions for preventing } \\
\text { infection with Middle East respiratory syndrome coronavirus (MERS- } \\
\mathrm{CoV} \text { ) wherein the immunogenic compositions comprise at least a } \\
\text { portion of the MERS-CoV S protein and an immunopotentiator. }\end{array}$ & Jiang et al. 2018 \\
\hline 2019-11-21 & US20190351049A1 & Spike protein & $\begin{array}{l}\text { Human Antibodies to Middle East } \\
\text { Respiratory Syndrome - Coronavirus } \\
\text { Spike Protein }\end{array}$ & $\begin{array}{l}\text { The present invention provides monoclonal antibodies that bind to the } \\
\text { Middle East Respiratory Syndrome-Coronavirus (MERS-CoV) spike } \\
\text { protein, and methods of use. In various embodiments of the invention, } \\
\text { the antibodies are fully human antibodies that bind to MERS- } \\
\text { CoV spike protein. In some embodiments, the antibodies of the } \\
\text { invention are useful for inhibiting or neutralizing MERS-CoV activity, } \\
\text { thus providing a means of treating or preventing MERS infection in } \\
\text { humans. In some embodiments, the invention provides for a } \\
\text { combination of one or more antibodies that bind to the MERS- } \\
\text { CoV spike protein for use in treating MERS infection. In certain } \\
\text { embodiments, the one or more antibodies bind to distinct non- } \\
\text { competing epitopes comprised in the receptor binding domain of } \\
\text { the MERS-CoV spike protein. }\end{array}$ & Kyratsous et al. 2019 \\
\hline 2019-12-05 & US20190365925A1 & Antigen targets & $\begin{array}{l}\text { AAV vectors targeted to the central } \\
\text { nervous system }\end{array}$ & $\begin{array}{l}\text { The invention relates to chimeric AAV capsids targeted to the central } \\
\text { nervous system, virus vectors comprising the same, and methods of } \\
\text { using the vectors to target the central nervous system. The invention } \\
\text { further relates to chimeric AAV capsids targeted to oligodendrocytes, } \\
\text { virus vectors comprising the same, and methods of using the vectors to } \\
\text { target oligodendrocytes. }\end{array}$ & Gray and McCown, 2019 \\
\hline 2019-09-05 & JP2019146588A & Vaccine & Priming of an immune response & $\begin{array}{l}\text { The present invention provides a method for expanding and improving } \\
\text { an immune response and at the same time increasing the speed of a } \\
\text { response against a pathogenic antigen or a cancer antigen. A two-step } \\
\text { prime-boost method whereby the immune system is first primed with a } \\
\text { nucleic acid construct comprising an invariant chain or a variant } \\
\text { thereof, followed by a booster vaccine using any type of suitable } \\
\text { vaccine Administration) to sufficiently stimulate the immune response } \\
\text { generated by vaccine administration. }\end{array}$ & Thomsen et al. 2019 \\
\hline 2019-10-17 & US20190314497A1 & Treatment & $\begin{array}{l}\text { Compositions and methods for treating } \\
\text { viral infections through stimulated } \\
\text { innate immunity in combination with } \\
\text { antiviral compounds }\end{array}$ & $\begin{array}{l}\text { Embodiments are directed to compositions and methods for treating } \\
\text { viral infections. }\end{array}$ & Dickey et al. 2019a \\
\hline
\end{tabular}




\begin{tabular}{|c|c|c|c|c|c|}
\hline 2019-03-12 & US10226434B2 & Treatment & $\begin{array}{l}\text { Design, synthesis and methods of use } \\
\text { of acyclic fleximer nucleoside } \\
\text { analogues having anti-coronavirus } \\
\text { activity }\end{array}$ & $\begin{array}{l}\text { The present invention is directed to compounds, methods and } \\
\text { compositions for treating or preventing viral infections using } \\
\text { nucleosides analogs. Specifically, the present invention provides for } \\
\text { the design and synthesis of acyclic fleximer nucleoside analogues } \\
\text { having increased flexibility and ability to alter their conformation } \\
\text { structures to provide increased antiviral activity potential with the } \\
\text { result of inhibiting several coronaviruses. }\end{array}$ & $\begin{array}{l}\text { Radtke } \\
\text { et al. } 2019\end{array}$ \\
\hline 2020-02-04 & US10548971B2 & Vaccine & MERS-CoV vaccine & $\begin{array}{l}\text { Disclosed herein is a vaccine comprising a Middle East Respiratory } \\
\text { Syndrome coronavirus (MERS-CoV) antigen. The antigen can be a } \\
\text { consensus antigen. The consensus antigen can be a consensus spike } \\
\text { antigen. Also disclosed herein is a method of treating a subject in need } \\
\text { thereof, by administering the vaccine to the subject. }\end{array}$ & $\begin{array}{l}\text { Weiner } \\
\text { et al. } 2020\end{array}$ \\
\hline 2019-05-08 & $\begin{array}{l}\text { Publication of } \\
\text { JP6508605B2 }\end{array}$ & Vaccine & $\begin{array}{l}\text { Modular DNA binding domain and } \\
\text { method of use }\end{array}$ & $\begin{array}{l}\text { The present invention provides a method of selectively recognizing } \\
\text { base pairs in a target DNA sequence by a polypeptide, } \\
\text { A modified polypeptide that specifically recognizes one or more base } \\
\text { pairs within a target DNA sequence, and a DNA that is modified so } \\
\text { that it can be specifically recognized by the polypeptide, and a specific } \\
\text { D } \\
\text { Use of polypeptides and DNA in NA targeting and methods of } \\
\text { modulating expression of target genes in cells. }\end{array}$ & Bonus et al. 2019 \\
\hline 2019-09-10 & US10406229B2 & Vaccine & $\begin{array}{l}\text { Methods and compositions related to } \\
\text { inhibition of viral entry }\end{array}$ & $\begin{array}{l}\text { Disclosed herein are compositions and methods for inhibiting viral } \\
\text { entry. }\end{array}$ & Francis et al. 2019 \\
\hline $2018-12-20$ & AU2015340134B2 & $\begin{array}{l}\text { Antigenic gene } \\
\text { identification }\end{array}$ & $\begin{array}{l}\text { Microfluidic device for detecting target } \\
\text { gene, method for manufacturing same, } \\
\text { and method for detecting using same }\end{array}$ & $\begin{array}{l}\text { The present invention provides a target gene capable of being } \\
\text { differentiated by the naked eye by amplifying the target gene to } \\
\text { selectively block the fluid path and, specifically, a microfluidic device } \\
\text { for detecting pathogen genes, and a detection method using the same. } \\
\text { Therefore, the present invention can conveniently detect a single target } \\
\text { gene, such as a single pathogen, or at the same time, several target } \\
\text { genes, such as several pathogens, without complicated mechanical } \\
\text { devices. }\end{array}$ & Jung et al. 2018 \\
\hline 2018-01-30 & US9878024B2 & $\begin{array}{l}\text { Enhanced } \\
\text { immune } \\
\text { response }\end{array}$ & $\begin{array}{l}\text { Methods and compositions using } \\
\text { Listeria for enhancing immunogenicity } \\
\text { by prime boost }\end{array}$ & $\begin{array}{l}\text { Provided herein are prime-boost regimens and materials used therein. } \\
\text { The prime-boost regimens enhance the immune response to a target } \\
\text { antigen. The vaccines used for boost are comprised of recombinant } \\
\text { attenuated metabolically active Listeria that encodes an expressible }\end{array}$ & Dubensky et al. 2018 \\
\hline
\end{tabular}




\begin{tabular}{|c|c|c|c|c|c|}
\hline & & & & $\begin{array}{l}\text { antigen that is cross-reactive with the target antigen. In some } \\
\text { examples, the immune response is a cellular immune response. }\end{array}$ & \\
\hline 2017-08-01 & US9719107B2 & $\begin{array}{l}\text { Recombinant } \\
\text { gene and protein } \\
\text { expression }\end{array}$ & $\begin{array}{l}\text { Construction of fully-deleted } \\
\text { adenovirus-based gene delivery vectors } \\
\text { and uses thereof }\end{array}$ & $\begin{array}{l}\text { The embodiments disclosed herein relate to the construction of fully- } \\
\text { deleted Adenovirus-based gene delivery vectors packaged without } \\
\text { helper Adenovirus, and more particularly to their use in gene therapy } \\
\text { for gene and protein expression, vaccine development, and } \\
\text { immunosuppressive therapy for allogeneic transplantation. In an } \\
\text { embodiment, a method for propagating an adenoviral vector includes } \\
\text { (a) providing an Adenovirus packaging cell line; (b) transfecting a } \\
\text { fully-deleted Adenoviral vector construct into the cell line; and } \\
\text { optionally (c) transfecting a packaging construct into the cell line, } \\
\text { wherein the fully-deleted Adenoviral vector construct and optionally } \\
\text { the packaging construct can transfect the Adenovirus packaging cell } \\
\text { line resulting in the encapsidation of a fully-deleted Adenoviral vector } \\
\text { independent of helper Adenovirus. In an embodiment, a target cell is } \\
\text { transduced with the encapsidated fully-deleted Adenoviral vector for } \\
\text { treating a condition, disease or a disorder. }\end{array}$ & Brennan et al. 2017 \\
\hline 2019-06-04 & US10307439B2 & Drug treatment & $\begin{array}{l}\text { Substituted nucleosides, nucleotides } \\
\text { and analogs thereof }\end{array}$ & $\begin{array}{l}\text { Disclosed herein are nucleosides, nucleotides and nucleotide analogs, } \\
\text { methods of synthesizing the same and methods of treating diseases } \\
\text { and/or conditions such as a Coronaviridae virus, a Togaviridae virus, a } \\
\text { Hepeviridae virus and/or a Bunyaviridae virus infection with one or } \\
\text { more nucleosides, nucleotides and nucleotide analogs. }\end{array}$ & Blatt et al. 2019 \\
\hline $2008-05-22$ & WO2007062656A3 & Vaccine & A nucleotide vaccine & $\begin{array}{l}\text { The present invention relates to a vaccine comprising a nucleic acid } \\
\text { construct such as a DNA construct especially a nucleic acid construct } \\
\text { comprising sequences encoding invariant chain operatively linked to } \\
\text { antigenic protein or peptide encoding sequences. The vaccine } \\
\text { stimulates an immune response, especially an immune response in an } \\
\text { MHC-I dependent, but CD4+ T-cell independent manner. }\end{array}$ & Holst et al. 2008 \\
\hline $2018-01-23$ & US9872900B2 & Vaccine & Nucleic acid vaccines & $\begin{array}{l}\text { The invention relates to compositions and methods for the preparation, } \\
\text { manufacture and therapeutic use ribonucleic acid vaccines (NAVs) } \\
\text { comprising polynucleotide molecules encoding one or more antigens. }\end{array}$ & Ciaramella et al. 2018 \\
\hline 2019-05-14 & US10286065B2 & $\begin{array}{l}\text { Treatment and } \\
\text { immune } \\
\text { modulators }\end{array}$ & $\begin{array}{l}\text { Compositions and methods for treating } \\
\text { viral infections through stimulated } \\
\text { innate immunity in combination with } \\
\text { antiviral compounds }\end{array}$ & $\begin{array}{l}\text { Embodiments are directed to compositions and methods for treating } \\
\text { viral infections. }\end{array}$ & Dickey et al. 2019b \\
\hline
\end{tabular}




\begin{tabular}{|l|l|l|l|l|l|}
\hline 2019-10-09 & EP3194423B1 & $\begin{array}{l}\text { Treatment } \\
\text { antiviral }\end{array}$ & $\begin{array}{l}\text { Method for preparing a vaccine } \\
\text { antigen, resulting vaccine antigen and } \\
\text { uses }\end{array}$ & $\begin{array}{l}\text { The present invention relates to a method for preparing a vaccine } \\
\text { antigen comprising a membrane protein, as well as to a vaccine } \\
\text { antigen and a vaccine, and uses thereof. }\end{array}$ & \begin{tabular}{l} 
Rosa-Calatrava et al. 2019 \\
\hline 2018-11-20
\end{tabular} \\
& US10130701B2 & $\begin{array}{l}\text { Treatment/ } \\
\text { vaccine }\end{array}$ & Coronavirus & $\begin{array}{l}\text { The present invention provides a live, attenuated coronavirus } \\
\text { comprising a variant replicase gene encoding polyproteins comprising } \\
\text { a mutation in one or more of non-structural protein(s) (nsp)-10, nsp- } \\
14, \text { nsp-15 or nsp-16. The coronavirus may be used as a vaccine for } \\
\text { treating and/or preventing a disease, such as infectious bronchitis, in a } \\
\text { subject. }\end{array}$ \\
\hline
\end{tabular} \\ doi:10.20944/preprints202004.0075.v1}

